
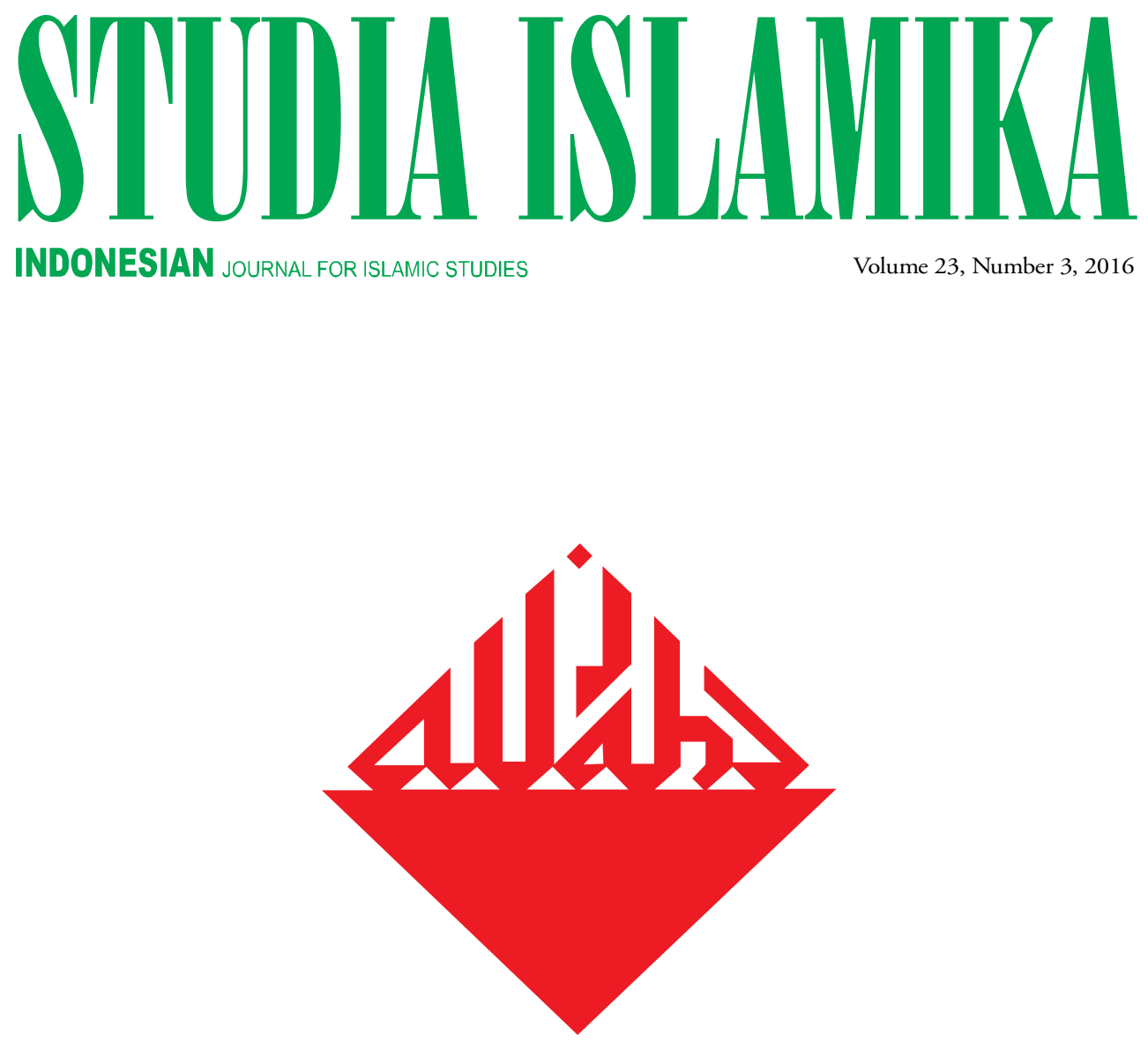

A Genealogy of Moderate Islam:

Governmentality and Discourses of Islam in Indonesia's Foreign Policy

Ahmad Rizky Mardhatillah Umar

Islamic School and Arab Association: Ahmad Sūrkatī’s Reformist Thought and Its Influence on the Educational Activities of AL-IrshāD

Motoki Yamaguchi

Post-IsLamism and the Remaking of Islamic Public Sphere in Post-reform Indonesia Muhammad Ansor 
STIUDLA ISLAMIIIKA 



\section{STIDIA ISLAMIIKA}

Indonesian Journal for Islamic Studies

Vol. 23, no. 3, 2016

EDITOR-IN-CHIEF

Azyumardi Azra

MANAGING EDITOR

Oman Fathurahman

\section{EDITORS}

Saiful Mujani

Jamhari

Didin Syafruddin

Jajat Burhanudin

Fuad Jabali

Ali Munhanif

Saiful Umam

Ismatu Ropi

Dadi Darmadi

Jajang Jahroni

Din Wahid

Ayang Utriza Yakin

INTERNATIONAL EDITORIAL BOARD

M. Quraish Shihab (Syarif Hidayatullah State Islamic University of Jakarta, INDONESIA)

Taufik Abdullah (Indonesian Institute of Sciences (LIPI), INDONESIA)

M.C. Ricklefs (Australian National University, AUSTRALIA)

Martin van Bruinessen (Utrecht University, NETHERLANDS)

John R. Bowen (Washington University, USA)

M. Kamal Hasan (International Islamic University, MALAYSIA)

Virginia M. Hooker (Australian National University, AUSTRALIA)

Edwin P. Wieringa (Universität zu Köln, GERMANY)

Robert W. Hefner (Boston University, USA)

Rémy Madinier (Centre national de la recherche scientifique (CNRS), FRANCE)

R. Michael Feener (University of Oxford, UK)

Michael F. Laffan (Princeton University, USA)

\section{ASSISTANT TO THE EDITORS}

Testriono

Muhammad Nida' Fadlan

ENGLISH LANGUAGE ADVISOR

Kevin W. Fogg

ARABIC LANGUAGE ADVISOR

Tb. Ade Asnawi

Nursamad

COVER DESIGNER

S. Prinka 
STUDIA ISLAMIKA (ISSN 0215-0492; E-ISSN: 2355-6145) is an international journal published by the Center for the Study of Islam and Society (PPIM) Syarif Hidayatullah State Islamic University of Jakarta, INDONESIA. It specializes in Indonesian Islamic studies in particular, and Southeast Asian Islamic studies in general, and is intended to communicate original researches and current issues on the subject. This journal warmly welcomes contributions from scholars of related disciplines. All submitted papers are subject to double-blind review process.

STUDIA ISLAMIKA has been accredited by The Ministry of Education and Culture, Republic of Indonesia as an academic journal (SK Dirjen Dikti No. 56/DIKTI/Kep/2012).

STUDIA ISLAMIKA has become a CrossRef Member since year 2014. Therefore, all articles published by STUDIA ISLAMIKA will have unique Digital Object Identifier (DOI) number.

STUDIA ISLAMIKA is indexed in Scopus since 30 May 2015. Therefore, all articles published since 2015 also will be appeared there.

(C) Copyright Reserved

Editorial Office:

STUDIA ISLAMIKA, Gedung Pusat Pengkajian

Islam dan Masyarakat (PPIM) UIN Jakarta,

Jl. Kertamukti No. 5, Pisangan Barat, Cirendeu,

Ciputat 15419, Jakarta, Indonesia.

Phone: (62-21) 7423543, 7499272, Fax: (62-21) 7408633;

E-mail: studia.islamika@uinjkt.ac.id

Website: http://journal.uinjkt.ac.id/index.php/studia-islamika

Annual subscription rates from outside Indonesia, institution: US\$ 75,00 and the cost of a single copy is US\$ 25,00; individual: US\$ 50,00 and the cost of a single copy is US\$ 20,00. Rates do not include international postage and handling.

Please make all payment through bank transfer to: PPIM, Bank Mandiri KCP Tangerang Graha Karnos, Indonesia, account No. 101-00-0514550-1 (USD),

\section{Swift Code: bmriidja}

Harga berlangganan di Indonesia untuk satu tahun, lembaga:

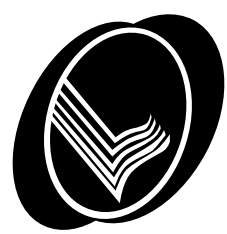
Rp. 150.000,-, harga satu edisi Rp. 50.000,-; individu: Rp. 100.000,-, harga satu edisi Rp. 40.000,-. Harga belum termasuk ongkos kirim.

Pembayaran melalui PPIM, Bank Mandiri KCP Tangerang Graha Karnos, No. Rek: 128-00-0105080-3 


\section{Table of Contents}

\section{Articles}

399 Ahmad Rizky Mardhatillah Umar

A Genealogy of Moderate Islam:

Governmentality and Discourses of Islam

in Indonesia's Foreign Policy

435 Motoki Yamaguchi

Islamic School and Arab Association:

Ahmad Sūrkatî’s Reformist Thought and Its Influence

on the Educational Activities of al-Irshād

471 Muhammad Ansor

Post-Islamism and the Remaking of

Islamic Public Sphere in Post-reform Indonesia

517 M. Adib Misbachul Islam

Al-Ṭarīqah wa al-ḥarakah al-iḥtijājīyah

al-ijtimā'īyah bi Jawa fī al-qarn al-tāsi' 'ashar:

Al-Shaykh Aḥmad al-Rifāōi Kalisalak Namūdhajan

561 Muhamad Firdaus Ab. Rahman \& Muhammad Amanullah Ta'bīd al-waqf wa ta'qìtuhu fī wilāyāt mukhtārah fī Malaysia 


\section{Book Review}

605 Zulkifli

Kesalehan 'Alawi dan Islam di Asia Tenggara

\section{Document}

625 Abdallah

Exclusivism and Radicalism in Schools:

State Policy and Educational Politics Revisited 
M. Adib Misbachul Islam

Al-Ṭarīqah wa al-ḥarakah al-iḥtijājīyah
al-ijtimā‘̄iyah bi Jawa fī al-qarn al-tāsi ‘ ‘ashar:
Al-Shaykh Aḥmad al-Rifā‘n Kalisalak Namūdhajan

Abstract: This article delves into a manuscript of Nazam Tarekat written by Kiai Ahmad ar-Rifai Kalisalak. So far, there has been no study related to Kiai Ahmad ar-Rifai Kalisalak which used Nazam Tarekat as the primary source. The research on this manuscript and its social context highlights the special nature of Kiai Ahmad ar-Rifais teachings on Sufism, such as his attitude toward Javanese traditional leaders who have abandoned morality. The other special feature of his teachings on Sufism is that they show the determination of alim adil based on fiqh as the qualification for Suft teachers. The analysis of this alim adil concept as the qualification for Sufi teachers, put into the dynamics of socio-religious movements in 19th century Java, reveals that besides being a qualification for teachers of Sufism, alim adil also became the ideology for the social protest movement against Dutch colonialization in Java. The strength of the figh factor in the concept of alim adil indicates that Kiai Ahmad ar-Rifai Kalisalak's movement was far from messianic-millenarianism.

Keywords: Alim Adil, Fasik, Kiai Ahmad ar-Rifai Kalisalak, Nazam Tarekat, Social Protest. 
Abstrak: Artikel ini mengulas naskah nazam Tarekat karya Kiai Ahmad arRifai Kalisalak. Sejauh ini, belum ada studi tentang Kiai Abmad ar-Rifai Kalisalak yang menggunakan nazam Tarekat sebagai sumber primer. Telaah terhadap teks nazam Tarekat dan konteksnya memperlihatkan kekhasan ajaran tarekat Kiai Ahmad ar-Rifai, seperti yang terlihat dari kaitan langsung antara ajaran tarekatnya dengan sikap perlawanan terhadap para elite kepemimpinan tradisional Jawa yang mengalami dekadensi moral. Kekhasan lain dari ajaran tarekat Kiai Ahmad ar-Rifai terlihat dari penetapan alim adil yang bersumber dari ajaran fikih sebagai kualifikasi guru tarekat. Analisis gagasan alim adil sebagai syarat untuk guru tarekat, yang menempatkannya dalam dinamika gerakan sosial keagamaan di Jawa pada abad ke-19, menunjukkan bahwa di samping sebagai kualifkasi guru tarekat, alim adil juga menjadi ideologi bagi gerakan protes sosial dalam melawan kolonialisme yang melanda kawasan Jawa. Kuatnya unsur fikih dalam gagasan alim adil dengan sendirinya menunjukkan bahwa gerakan Kiai Ahmad ar-Rifai jauh dari unsur-unsur millenarianisme yang mesianistik.

Kata kunci: Alim Adil, Fasik, Kiai Ahmad ar-Rifai, Nazam Tarekat, Protes Sosial.

الملخص: عالج هذا المقال مخطوط نظم الطريقة الذي كتبه الشيخ أحمد الرفاعي

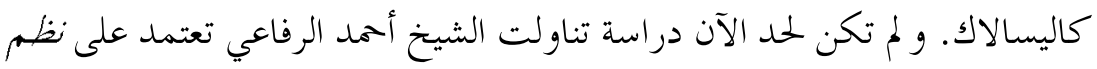

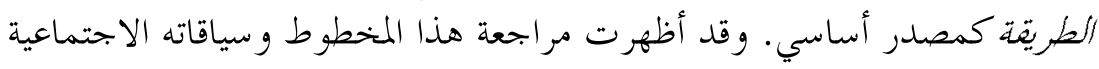

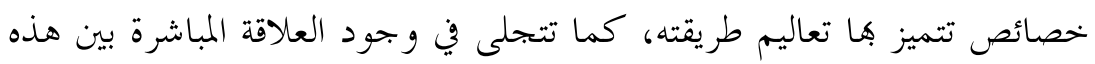

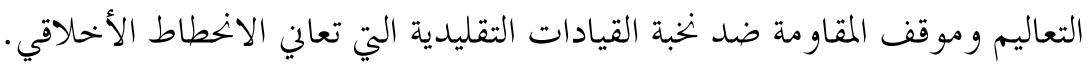

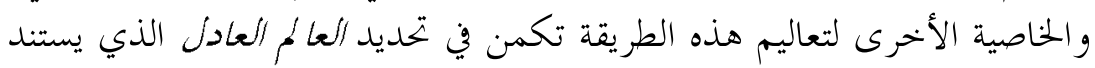

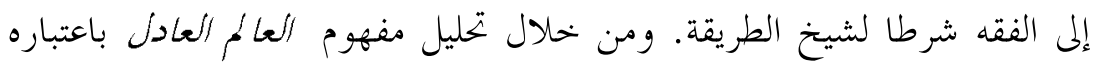

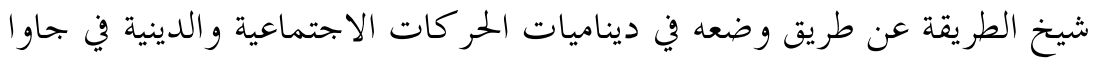

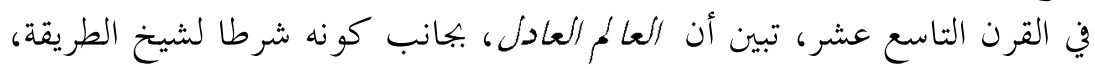

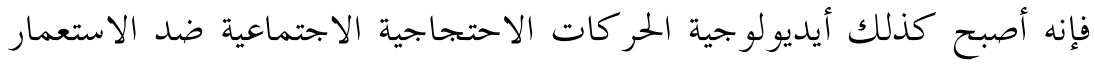

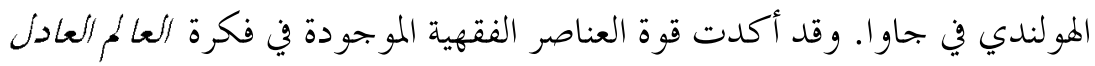
أن حركة الشيخ أحمد الرفاعي بعيدة عن العناصر الألفية والمهلدية.

الكلمات المفتاحية: العالم العادل، الفاسق، الشيخ أحمد الرفاعي، نظمم الطريقة،

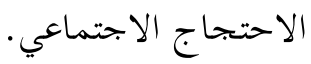




$$
\text { محمد أديب مصباح الإسلام }
$$

\section{الطريتمة والحركة الامتجاجية}

\section{الاجتهاعية يجاها هيى المترن التزاسع عشر:}

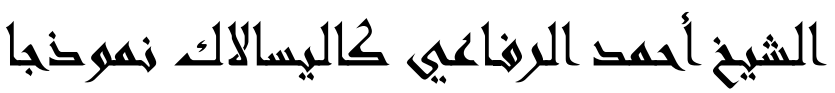

إن وجود الطريقة في منطقة نوسانتارا يمكن تتابع آثارها إلى القرن

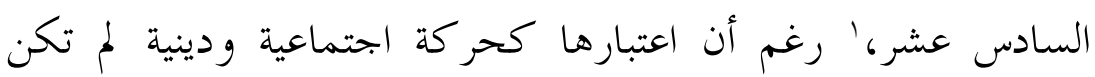

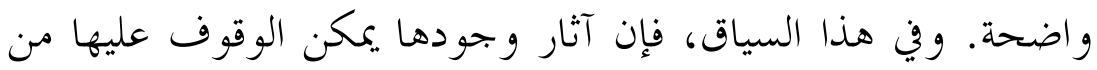

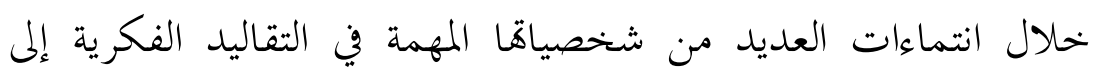

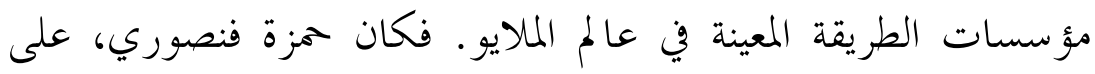

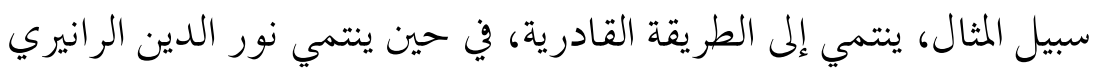

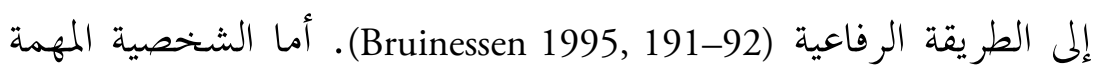

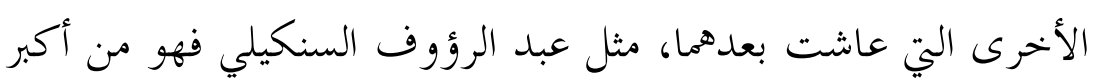

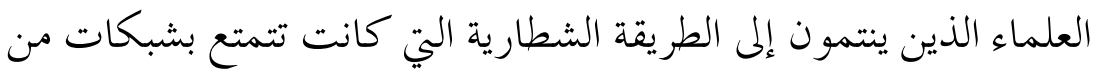
المريدين امتدت إلى جاوا ا (Bruinessen 1995, 192; Fathurahman 2008 $.32,91)$ 
إن الطريقة، باعتبار ها جزءا لا يتجز أ من الصوفية، تتميز تعاليمها بطابع أخلاقي روحاني. ولذلك، فإنه ليس من المستغرب أن يؤثر هذا الاتحاه

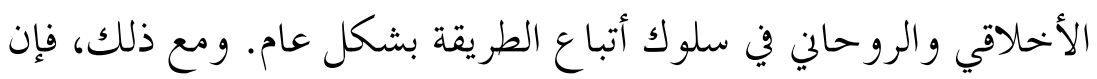

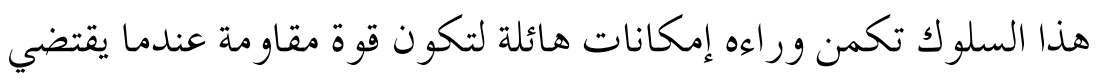
الأمر إلى ذلك، كما حدث في مختلف الحركات التي قامت هـا الطريقة ضد الاستعمار . وقد أظهرت دراسات حول حركات المقاومة في جاوا

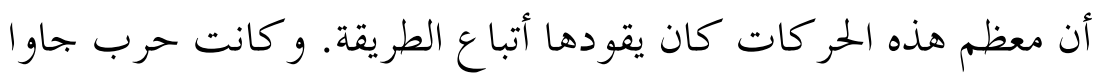
التي يقودها بانغير ان ديبو نيغار ا Pangeran Diponegoro، على سبيل المثال،

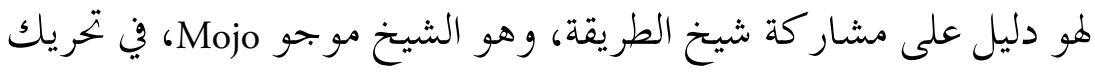

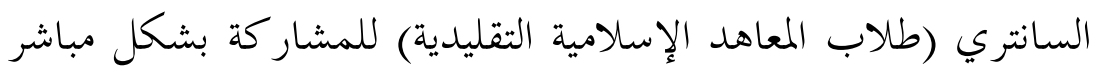
في تلك الحرب (Carey 2011, 131). وبالإضافة إلى ذلك، هناك دليل آخر على مشاركة أتباع الطريقة في مقاومة الاستعمار الهولندي يتمثل في مقاو مة فلاح بنتن التي حركتها شبكة من علماء البيسانترين و شيوخ الطريقة في تلك المنطقة، مثل الحاج عبد الكريم، و الحاج إسماعيل، والحاج مرزوقي، والحاج واسد، و ذلك في أواخر القرن التاسع عشر مartodirdjo)

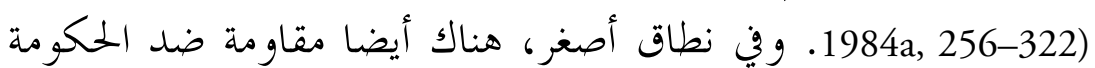
الاستعمارية من قبل أتباع الطريقة الأكملية، مثل الشيخ حسن ماولاني، و ماس مالانغ يودا، والشيخ نور حكيم، حيث كانت هذه المقاومة تتم

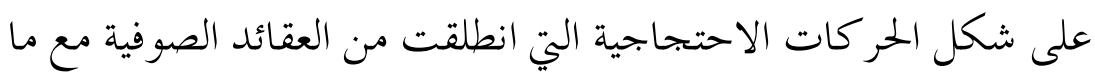
يصاحبها من التطلعات المهدية (messianic) (Ricklefs 2007, 47) . في الواقع، كان هؤلاء الشخصيات البارزة تلعب دورا هاما في تاريخ حركة المقاومة ضد الاستعمار. ومع ذلك، فإن العلاقة بين الطريقة و المقاومة من ناحية التعاليم، لا تزال تتطلب مزيدا من الدراسة، لاسيما في حالة عدم الكتب المتعلقة بالطريقة التي تستخدم عادة كدليل يعتمد 
عليه ممارسوها، والتي تتناول بصفة خاصة العلاقة بين الطريقة وموقف المقاومة. وحتى إذا كان هناك حديث عن الجهاد، فإن المراد به هو الجهاد كعىن النضال الروحي الذي يعرف في الأدب الصوفي بالمجاهدة، ب وليس. كعنى النضال المادي أو حتى النضال العسكري ضدي الند الطغيان.

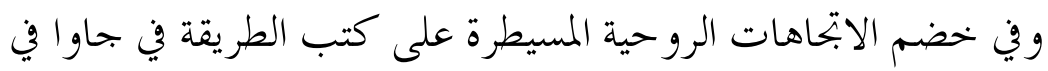
منتصف القرن التاسع عشر ظهر كتاب عن الطريقة تم تأليفه على شكل النظمّ بل إنه يحمل عنو ان 》الطريقة) ، وهذا الكتاب ألفه الشيخ أحمد الرفاعي كاليسالاك Kalisalak. و الشيء الملفت للاهتمام أن هذا النظم أظهر شيئا خارج منطقة الطريقة، وذلك من خلال ربط تعاليم الطريقة،

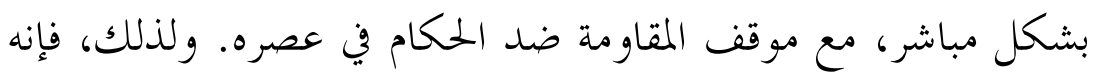
ليس من المبالغة إذا كان دربان Darban (2004, 12, 29) يعتبرها قصيدة تحتوي على عقيدة الاحتجاج والمقاومة ضد الحلكومة الاستعمارية و البيروقر اطية التقليدية.

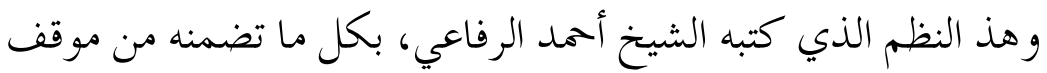
المقاومة أظهر جانبا آخر من فكره الذي لم يتم الكشف عنه بعد، وهو جوانب الطريقة وعلاقتها بموقف المقاومة ضد الاستعمارية. لذلك، في إطار محاولة للكشف عن هذه الجموانب، فإن دراسة هذا النظم أصبحت

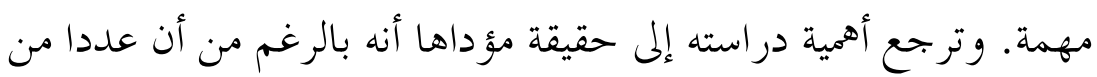

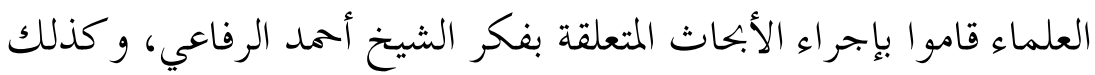

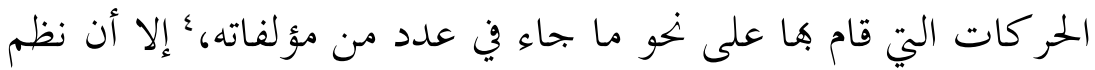

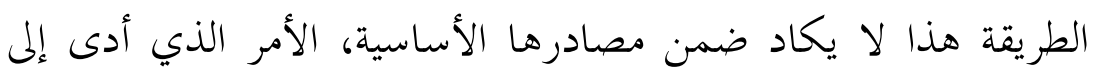
حدوث جدل بين العلماء حول الطريقة التي يتبناها الشيخ أحمد الرفاعي. وعلى سبيل المثال، قام كل من ألوان خيري، وجميل، وإصلاح غوسميان، و مصباح الإسلام بدراسة هذه الطريقة اعتمادا على مفهوم الطريقة الذي 
اشتهر عموما في الخطاب الصوفي ومفهومها كمنظمة روحية، ؛إلا أنه من المؤسف أن هؤلاء الباحثين لا يعتمدون في معالمتها على كتابه الذي يحمل بشكل خاص عنو ان 》الطريقة) . و من ناحية أخرى، فإن حضور نظم الطريقة الذي يحتوي بكل ما يحتويه

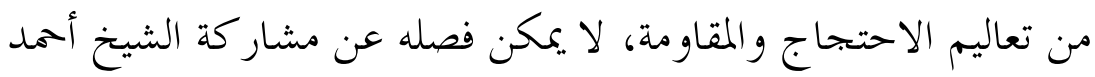
الرفاعي في الحركات الدينية ضد الاستعمار في ظل الأوضاع الاجتماعية التي حدثت بجاوا في القرن التاسع عشر الذي شهد الاضطرابات الاجتماعية المتزامنة مع التغيرات الاجتماعية نتيجة الهيمنة الغربية على مناطق جاوا (Kartodirdjo 1984a, 1). و وفي مثل هذه الحالات، ظهرت الحركات الاحتجاجية المختلفة ضد السيطرة الاستعمارية في المناطق الريفية بجاوا، والتي تتمثل كلها تقريبا في ما يعرف بحركة لاراتو أديل《يك Ratu Adil الاحتجاج التي سبق أن وقعت في عهد الاضطرابات السالالية (dynastic) .(Kartodirdjo 1984b, 39) و خلافا للحركات الاحتجاجية التي حدثت في جاوا بصفة عامة، و التي تحمل فكرة الالملكة العادلة|، فإن الشيخ أحمد الرفاعي يأتي بفكرة 》العالم العادل《 كأساس لحر كاته الاحتجاجية الاجتماعية والدينية ضد نخبة القادة التقليديين في جاوا الذين كانوا يعانون الانخطاط الأخحاقي، محا أدى إلى تحقيق العلاقات التعارضية بين عالم و جاهل، وبين عادل وفاسق. ولذلك، فليس من المبالغة إذا اعتبر جميل Djamil (2001, 222)، أن فكرة

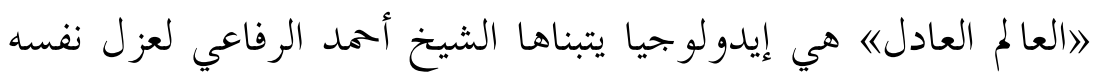

$$
\text { و أتباعه عن الحكام وأجهز همه. }
$$

ومن خلال حضور نظم الطريقة بكل خصائصه التي تعارض التيار

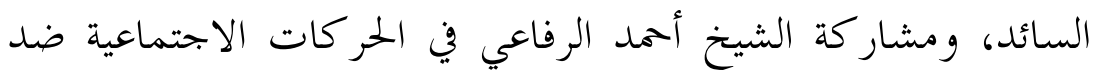


الاستعمار، كما سبق ذكره، يمكن التأكيد أن تعاليم الطريقة الواردة في

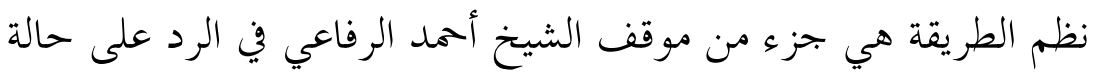

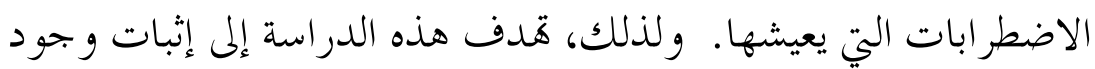

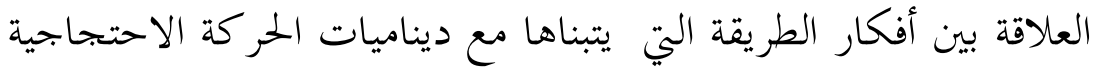

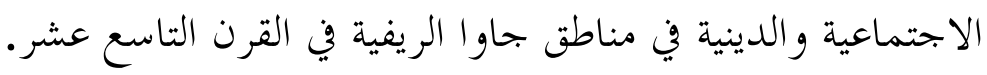

\section{الشيخ أحمد الرفاعي كاليسالاك في الديناميات

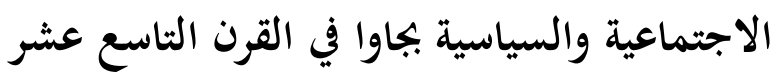

كان وجود الاستعمار الهولندي في جاوا في القرن التاسع عشر يو اجهه

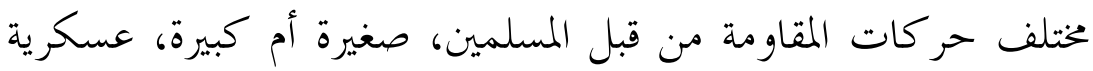

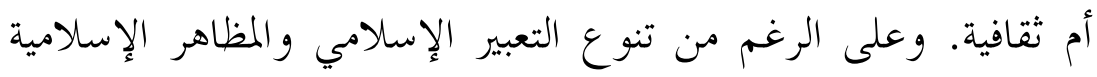

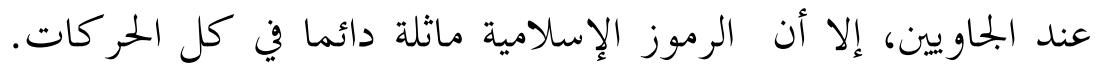

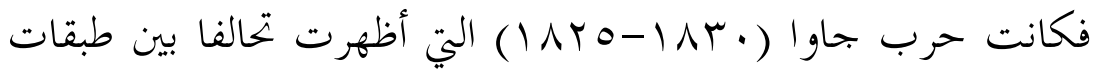

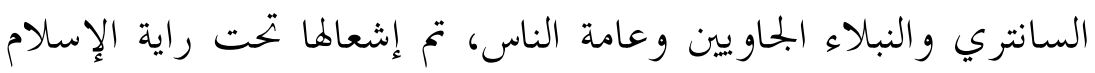

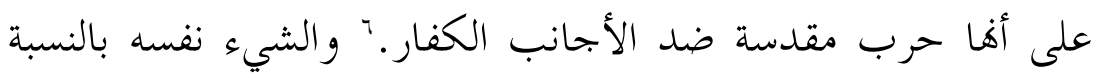

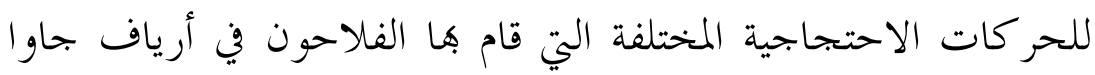

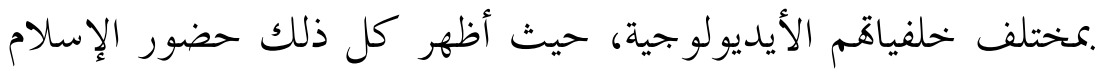

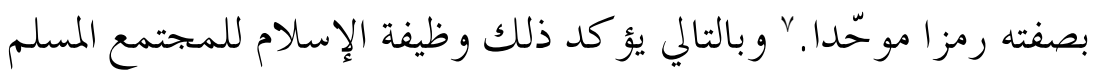
الإندونيسي عموما كنقطة الهوية التي تحدد قطع علاقاته بالقوى الأنس الأجنبية الكافرة ومقاو مته ضدها (Benda 1980, 32)

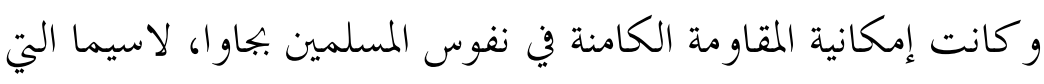

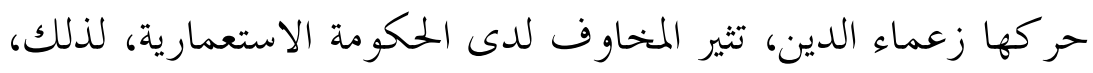

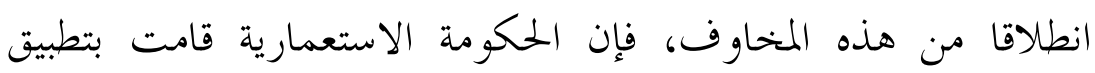

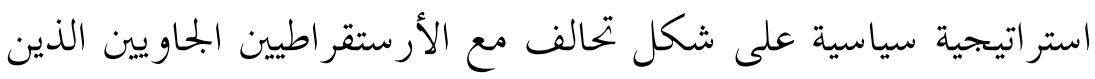


يُعتبرون غير متعصبين جدا للإسلام، بل ينظر إليهم على أهم يعارضون

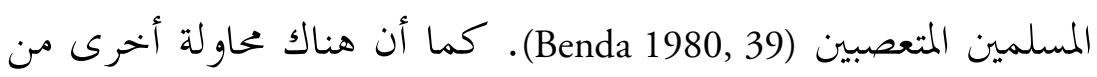
قبل الحلكومة الاستعمارية في إطار توقع ظهور مقاومة المسلمين تتمثل

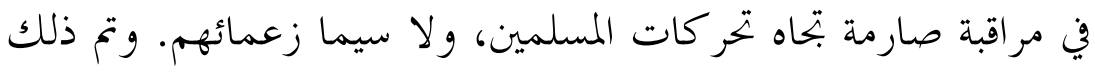
من خلال رؤساء البلديات .مساعدة القضاة (Penghulu) الذين حصلوا

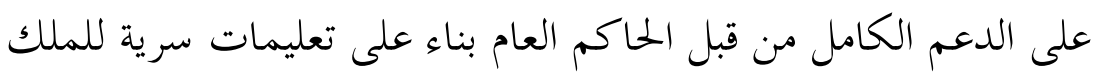
الهولندي (Suminto 1986, 3).

و هذه الاستراتيجية السياسية التي نفذها الحلكومة الاستعمارية من أجل سلطتها في جاوا لم تكن قادرة على منع بعض المسلمين فيها من إعادة

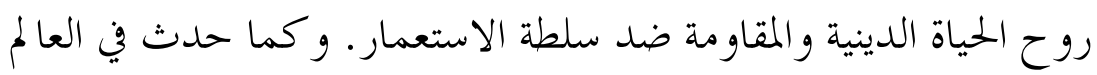

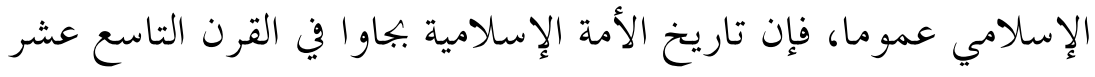
شهد تقدما ملحوظا في الأنشطة الدينية، بالإضافة إلى حر كات الإلى المقاومة الإسة

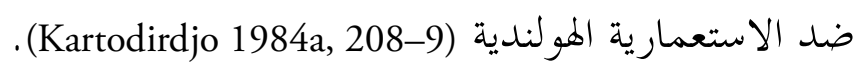
وفي أعقاب هضة الحياة الدينية من جديد، ومحاولة ترويض المسلمين من قبل سياسة الحلكومة المولندية، جاء الشيخ أحمد الرفاعي كاليسالاك وكاه (IVA Y- INV•)

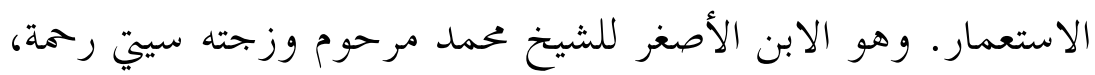

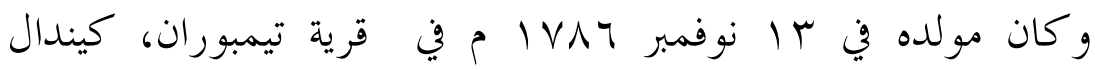
بسيمار انغ (Amin 1996, 42). و وبجانب دراسته في بيسانترين كاليوونغو Kaliwungu

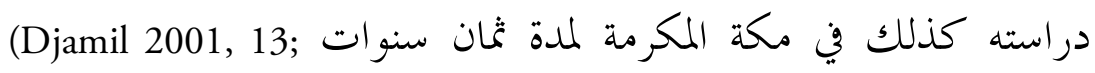
. Ismawati 2004, 215) وقد بدأت مشاركة الشيخ أحمد الرفاعي في حركة المقاومة ضد الحلكومة الاستعمارية منذ إقامته في كيندال، خاصة بعد عودته من مكة بكة 
المكرمة، وتزداد تكثيفا عندما استقر في كاليسالاك، باتانغ.^ لذلك، فإنه

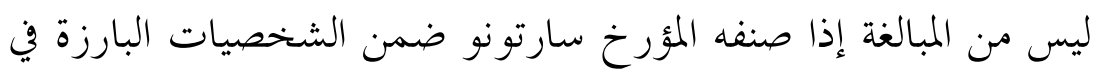

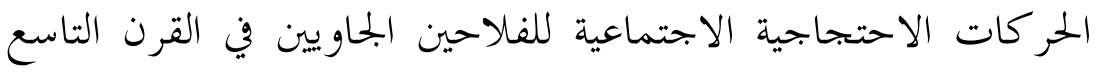

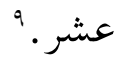

و ومما لا يمكن إنكاره أن روح المقاومة ضد الاستعمار التي تنمو داخل

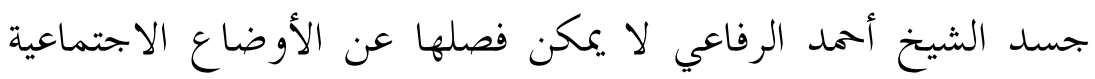

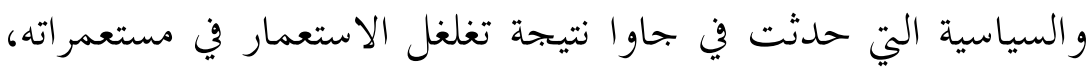

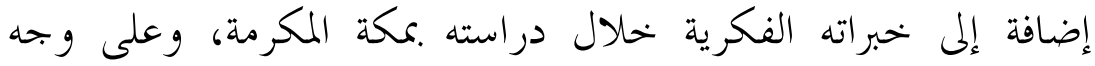
التحديد ما تعرضت له جاوا من التغيرات الاجتماعية نتيجة للمهود

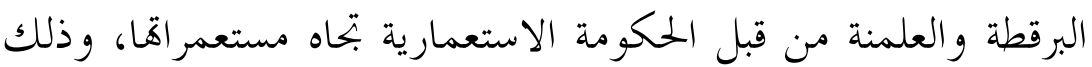

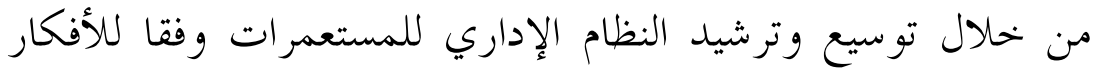

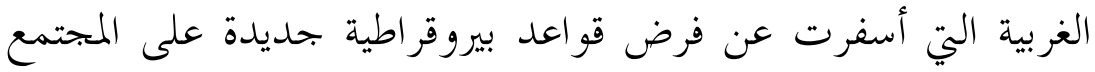

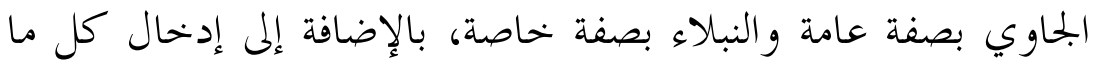

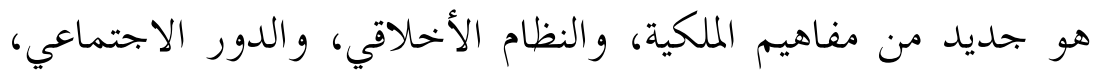

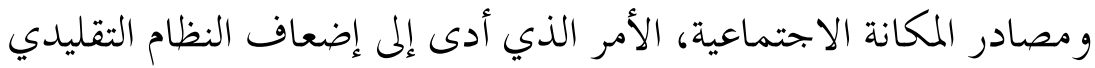

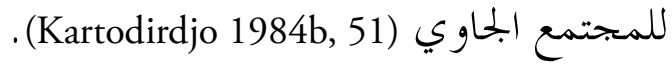

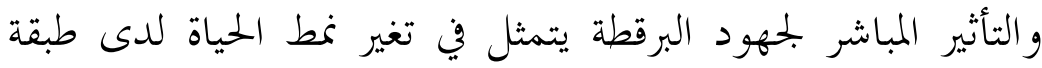

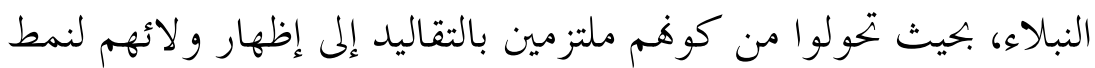

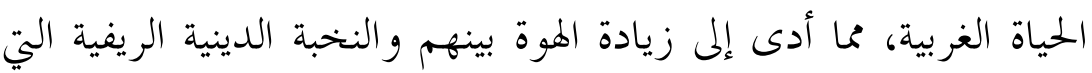

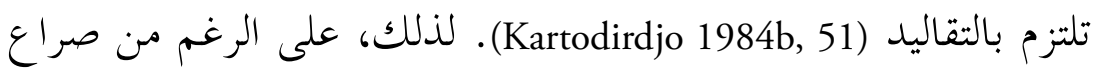

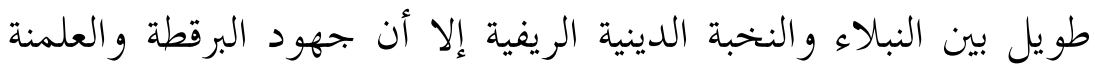

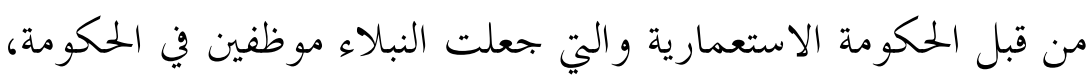

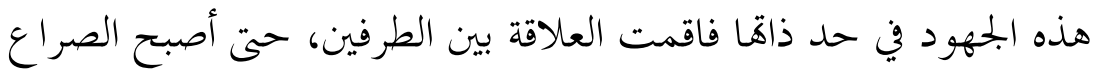
بينهما مفتوحا (Kartodirdjo 1984b, 51-52). 
وون ناحية أخرى، كانت عملية البرقطة التي تقوم بها الحكومة الاستعمارية لا تقتصر على جلب النبلاء في الوظائف الحلكومية أو الو

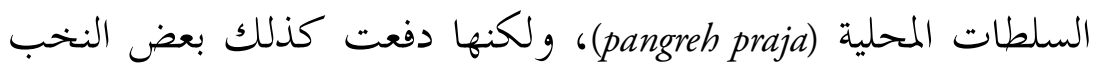
الدينية للدخول في المنطقة التي تحت مراقبتها. وفي خضم الجهود المختلفة من قبل الحكومة الاستعمارية، تقبل وتكيف بعض النخب الدينية، في هاية المطاف، مع النظام الاجتماعي الذي وضعته الحكومة الاستعمارية.

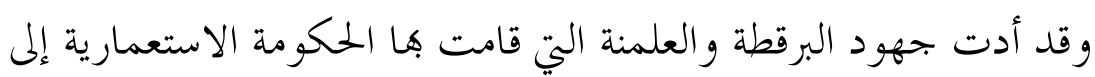

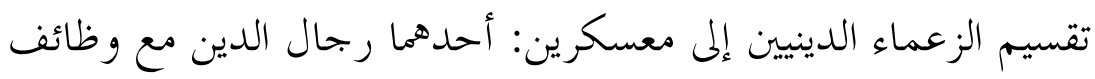
و سلطات معترف هما رسميا، وهم الذين يقبلون لأن يكونوا امتدادا

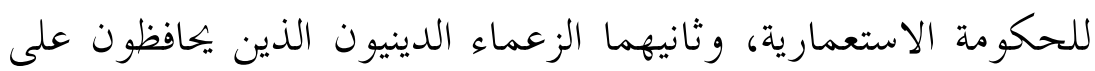
مسافة مع الحكومة في الوقت الذي يو اصلون نداءاتهم عن الروح الإحيائية

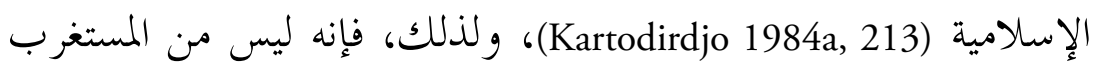

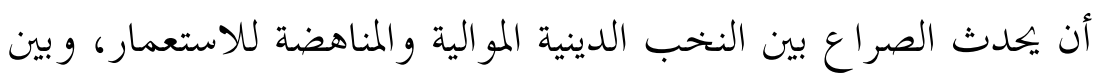
العلماء الحكو ميين و العلماء غير الحلكوميين (Kartodirdjo 1984a, 214). و وي خضم التغيير الاجتماعي نتيجة للتغلغل الاستعماري الذي ضرب

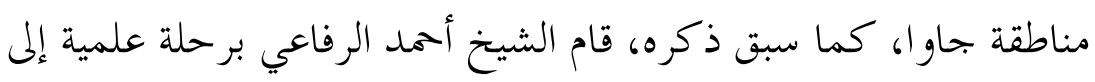

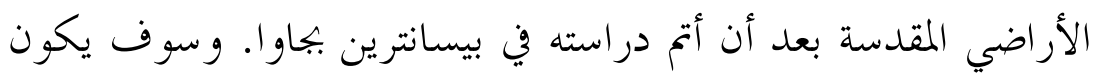
لهذه الفترة الدراسية التي استغرقت ثماني سنوات في الأراضي المقدسة (مكة المكرمة)، أثر كبير في عقليته. وذلك لأن بلد الحرمين الشريفين، منذ القرن السابع عشر، أصبح بقعة الانصهار (melting plot) للتقاليد

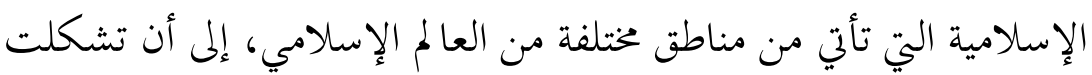

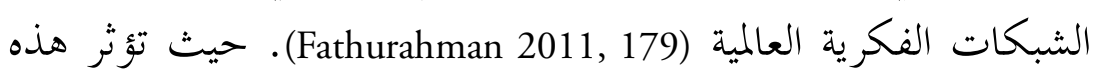
الشبكات، في هاية المطاف، في التقاليد العلمية المزدهرة في الأراضي المقدسة، وعلى وجه التحديد في بتحيد الفكر الإسلامي ونشره سواء 
عن طريق الكتابات أو التعليم، مع التركيز على تعزيز جوانب الشريعة الإسلامية دون بتحاهل المجوانب الصوفية (Azra 1999, 294).

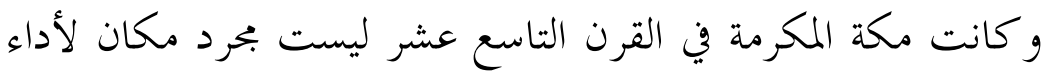

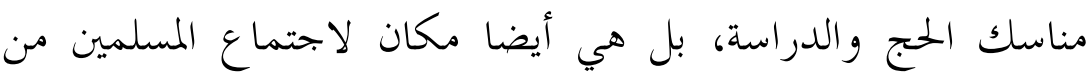

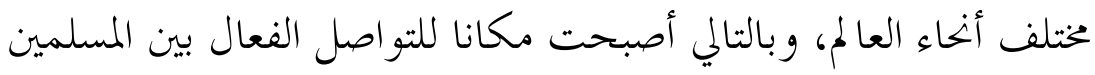
(Kartodirdjo 1984a, 210)

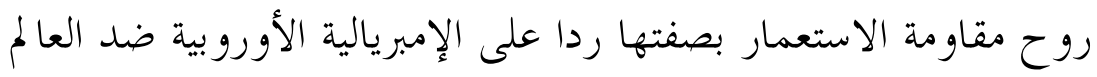

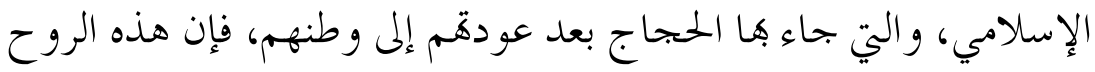

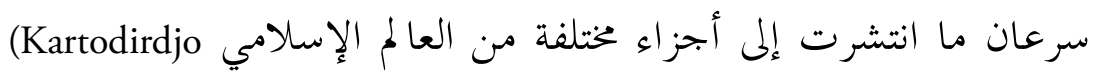

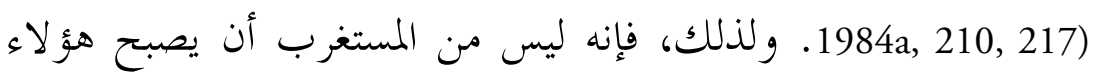

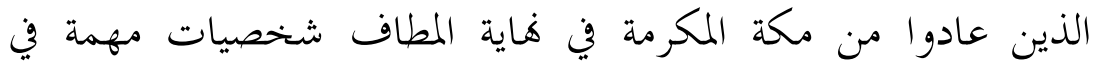

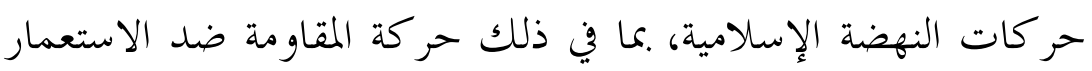
.(Kartodirdjo 1984a, 220-21)

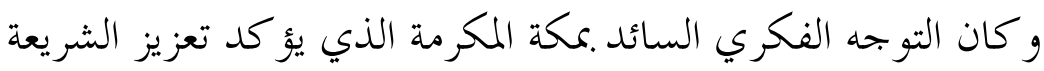

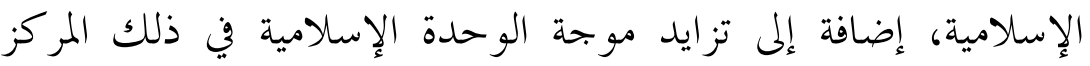
الإسلامي، كل ذلك يشجع على ظهور الوعي النشاطي لدى هؤلاء

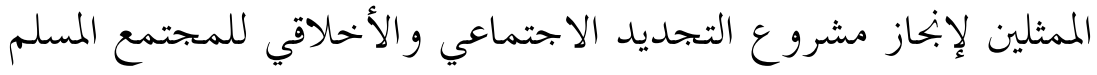
(Burhanudin 2012, 140-41; Rahman 2000, 282-84)

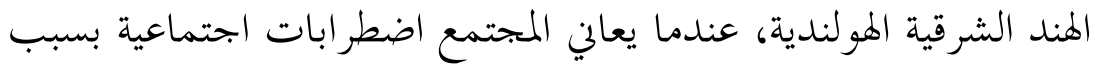

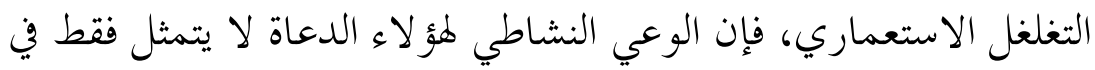

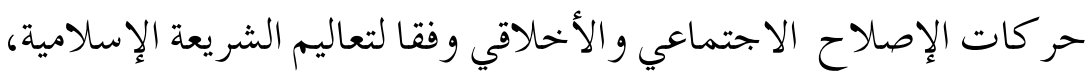

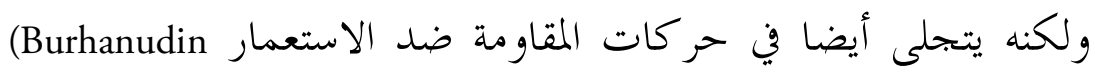

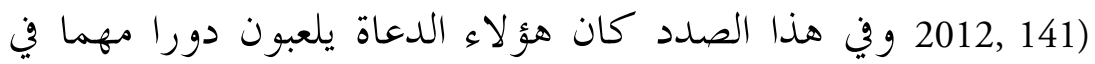

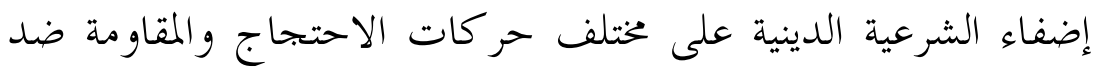


الاستعمار الهولندي، إضافة إلى جهودهم في إصلاح الحياة الاجتماعية و الدينية (Burhanudin 2012, 144). و كانت المقاومة التي يقوم هما الشيخ أحمد الرفاعي بصفته عالما منحدرا الرينا

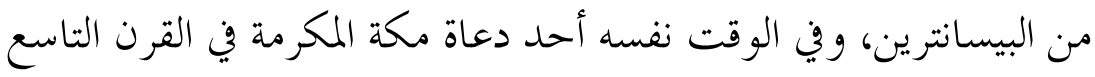

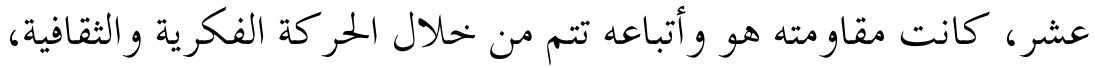

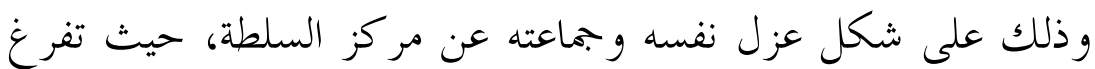

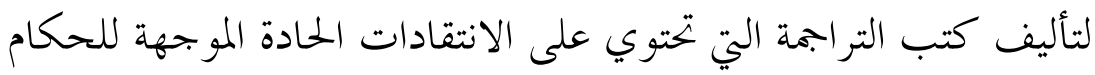

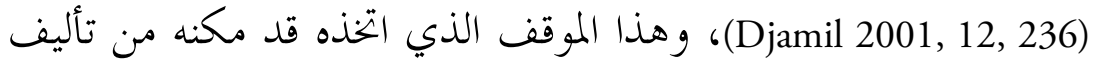

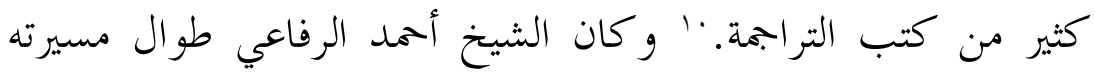

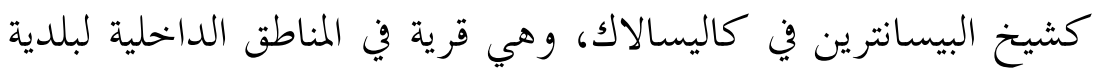

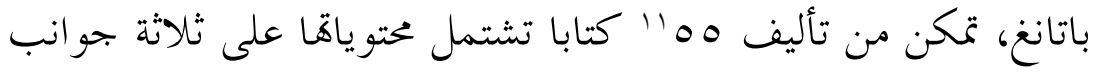

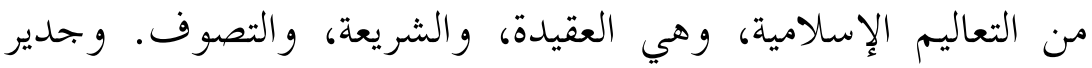

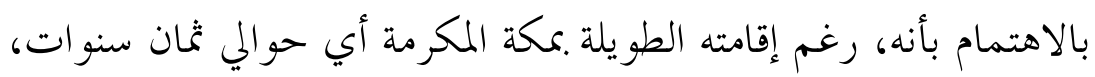

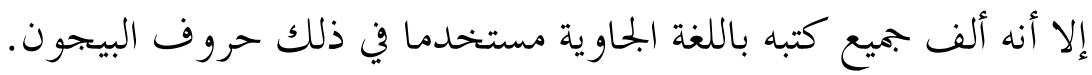

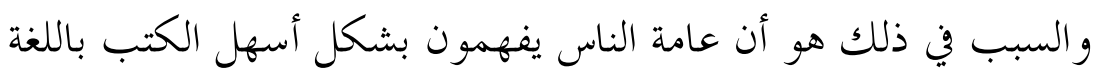

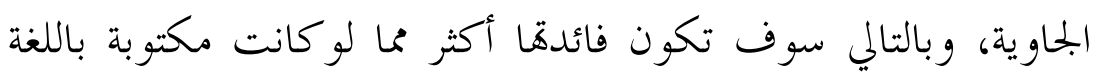

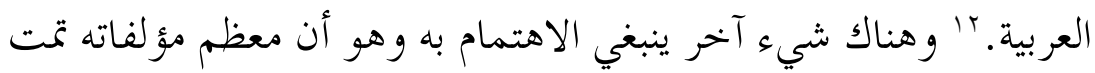

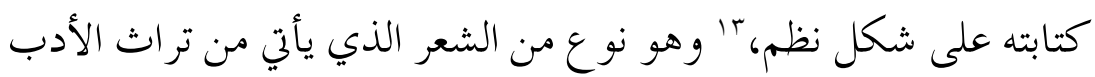

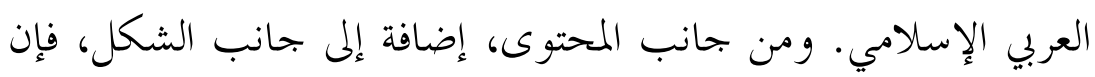

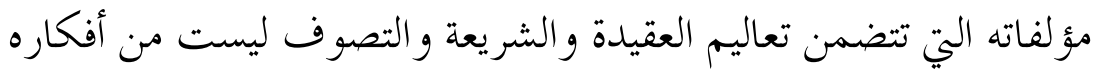

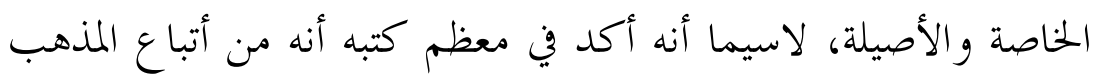

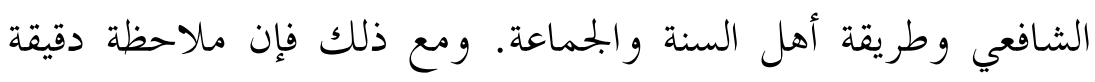

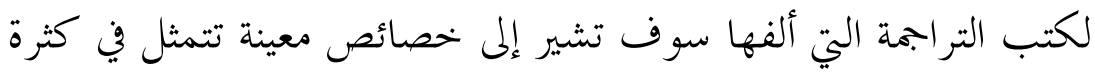

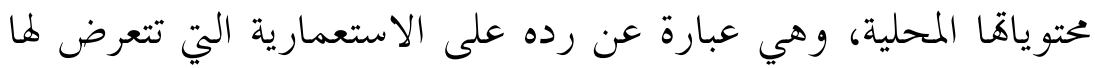


مناطق جاوا في القرن التاسع عشر، كما يدل على ذلك انظم الطريقة).

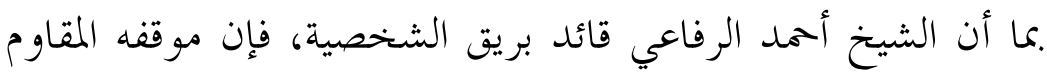

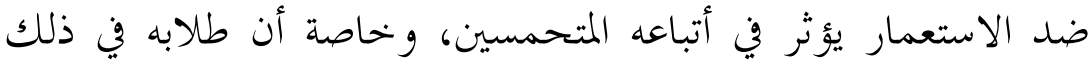

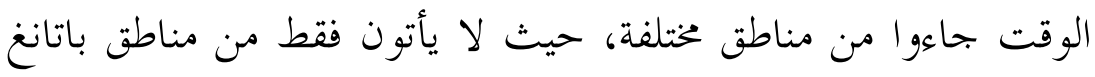

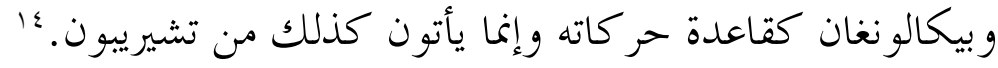
ومن وجهة نظر الحكومة الاستعمارية، فإن موقف المقاومة الذي تبناه

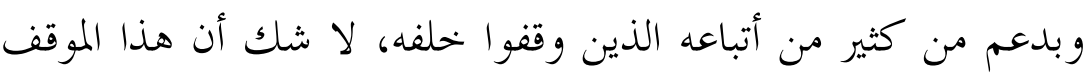

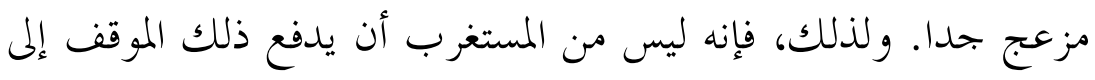

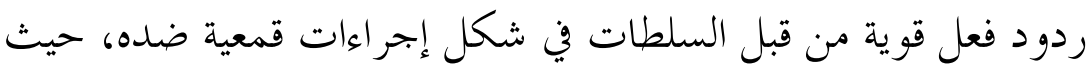

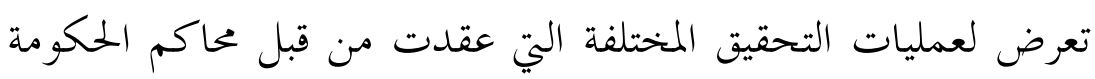

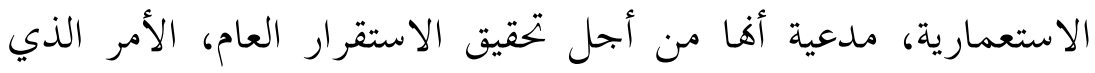

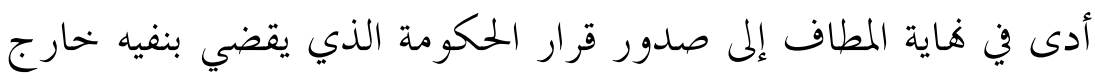
جاوا. 10

\section{مفهوم الطريقة عند الشيخ أحمد الرفاعي}

كما سبق ذكره في المقدمة، أن ححتوى نظم الطريقة مليء بروح المقاومة

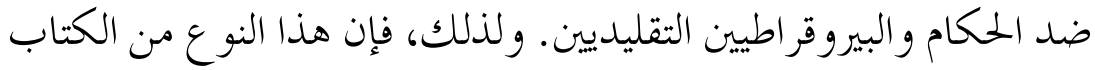

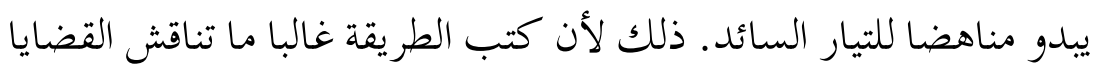

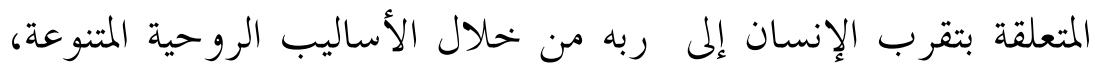

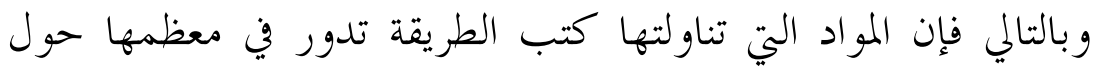

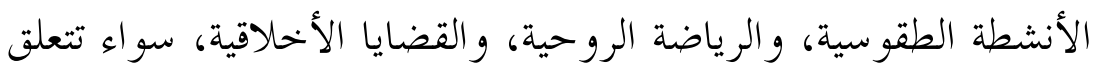

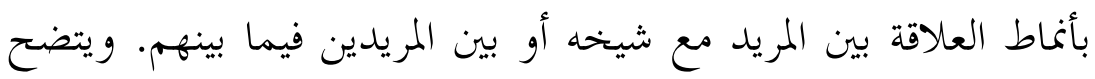

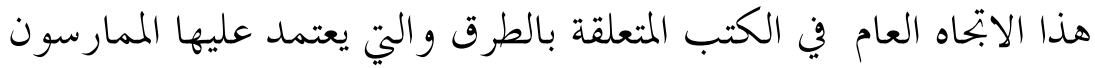

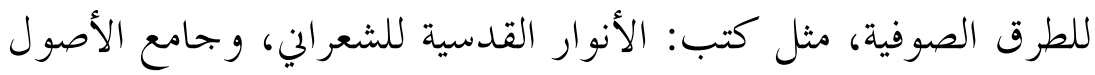


في الأولياء للكمشخانوي، وتنوير القلوب في معاملة علام الغيوب لمحمد أمين الكردي. و فيما يخص مفهوم الطريقة، يقول الشيخ أحمد الرفاعي في مقدمة نظم الطريقة:17 مك ايكي له كتاب أرن طريقة \# نظم ترجمة علم منفعة أخرة

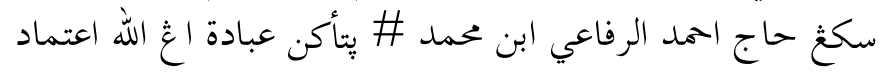

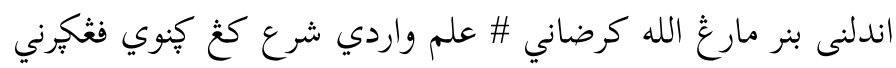

(Islam 2016, 79)

التر مهة:

هذا كتاب يسمى الطريقة \# نظم ترجمة يحتوي على علوم نافعة في الآخرة

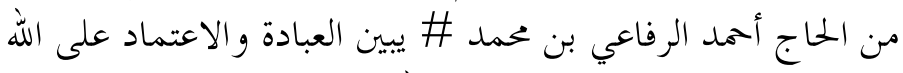

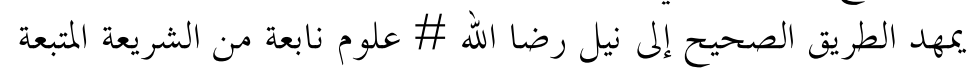
يوضح الشيخ أحمد الرفاعي في المقدمة أعلاه أن الطريقة هي فه الطريق الصحيح لنيل مرضاة الله، حيث يستمد في ذلك إلى أحكام الشريعة الإسلامية. وعلاوة على ذلك فقد حذر أن ممارسة الطريقة الصحيحة هي

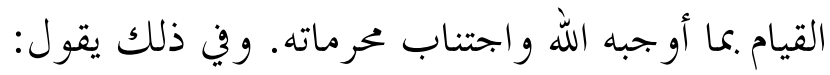
تنبيه طريقة بنر مارغ الله ملهور \# ايكو نتفي واجب سكغ حرام مغكور (Islam 2016, 15) التر مهة:

تنبيه، إن اختيار الطريقة الصحيحة إلى الله \#\# من خلال تنفيذ الواجبات واجتناب المحرمات المنيار الطريف

إن التوضيحات التي قدمها الشيخ أحمد الرفاعي يبدو للوهلة الأولى أها في غاية البساطة، حيث تقتصر على بحرد محاولة ذه الطريق الصحيح لنيل

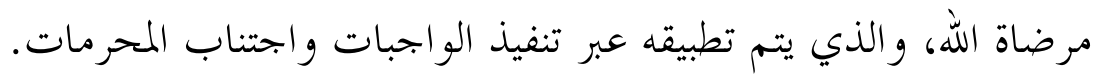


و وبناء على ذلك، في محاولة لفهم تعاليم طريقته، فإن نصوص نظم الطريقة الواردة في هذه الدراسة تمت مقارنتها مع كتب التصوف بصفة عامة و كتب الطريقة بصفة خاصة، وهي الكتب التي يستخدمها ممارسو الطريقة كمصادر أساسية.

وعلى الرغم من أنه يبدو بسيطا، فإن وجهات نظره هذه يمكن إرجاعها إلى التصوف الذي تبناه الجنيد، وهو صوفي كبير معتمد في

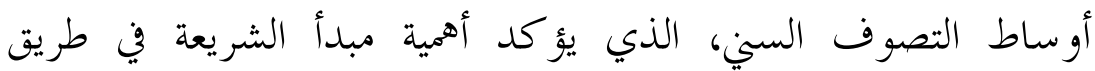
الصوفية. وقد توصل شرف (Sharaf 1984, 242) إلى أن الجنيد هو أول من صرح بوضوح أن 》الطريق إلى الله مسدود على خلق الله عز و جحل إلا الا

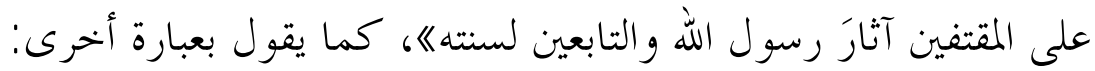
》امذهبنا هذا مقيد بالكتاب و السنة 《) (Sharaf 1984, 243).

و كان وجود التوافت بين طريقة الشيخ أحمد الرفاعي وتعاليم الجنيد ليس من قبيل الصدفة، فقد ذكر اسم الجنيد في نظم الطريقة، حيث يقول

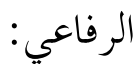
مجتهد مطلق اهل صوفى تنتر \# ايكو ابو قاسم جنيدى البغدادي مشهور طريقتى بنر مارغ الله فنلهر \# كويلغ عارف بالله سكغ لياني مغكور

(Islam 2016, 395) التر.مة:

المجتهد المطلق الصوفي المذكور \# هو أبو قاسم الجنيدي البغدادي المشهور

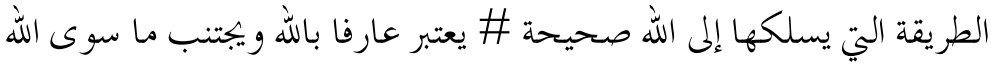
من خلال الاقتباس أعلاه، يرى الشيخ أحمد الرفاعي أن الجنيد هو

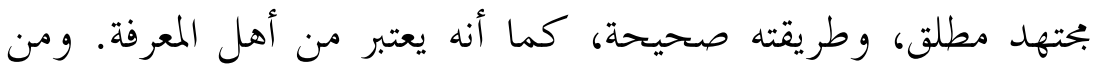
الملفت للاهتمام أن يعتبر الجنيد من أهل المعرفة كما يعتبره بحتهدا مطلقا،

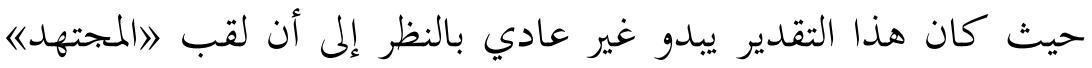


عادة ما يطلق في بحال العلوم الفقهية أو الأحكام الإسلامية. و بالتالي فإن

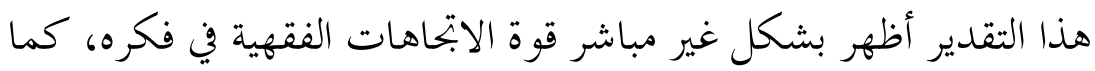

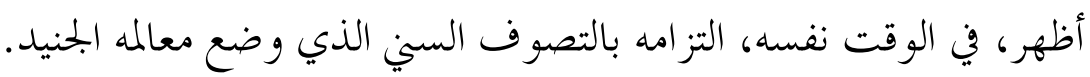

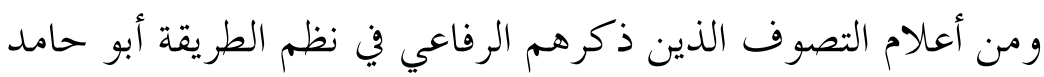

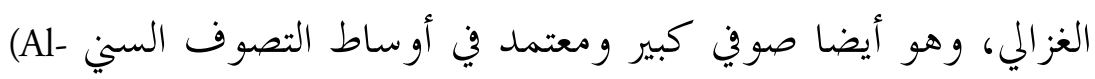

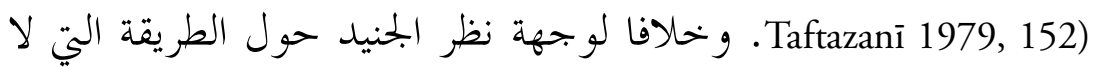

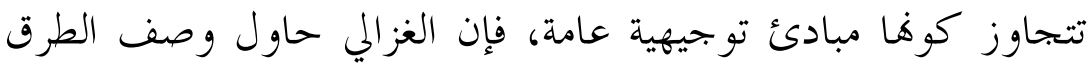

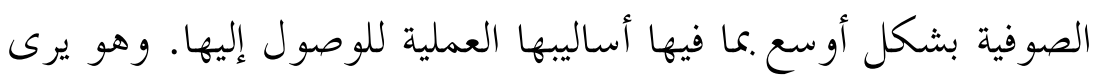

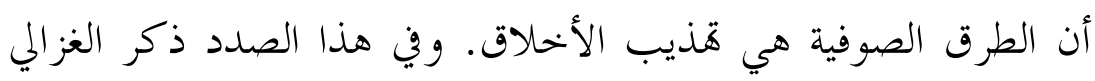
(Al-Ghazālī 2004, 4)

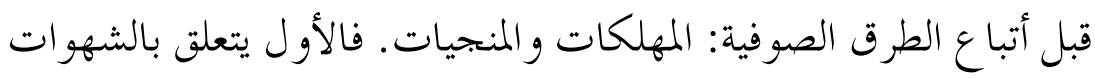

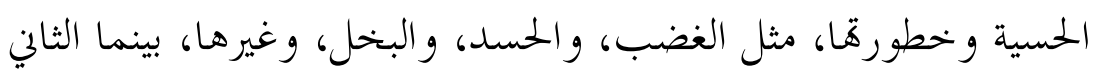

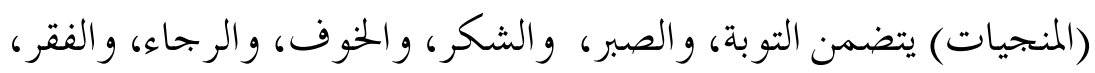

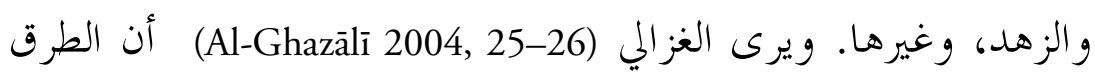
الصوفية هدف إلى تز كية القلب ليكون صافيا وجاهزا لقبول المعرفة.

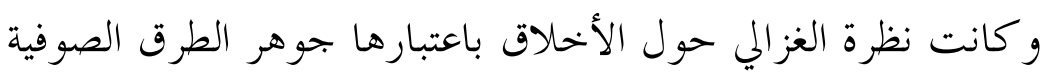

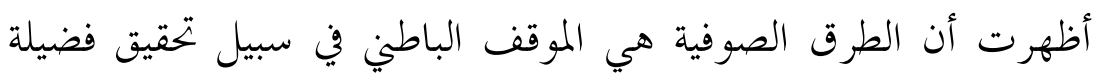

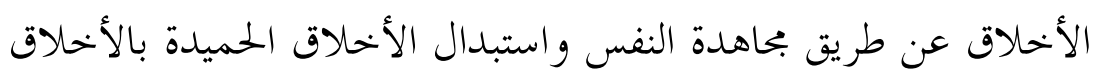

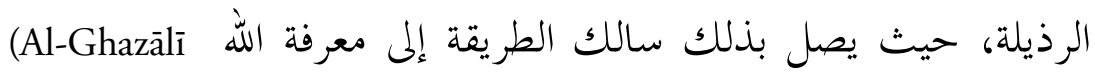

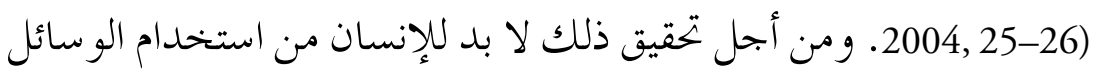

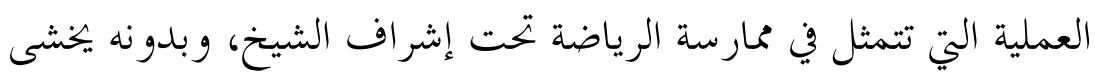
أن يضل الطريق (Al-Ghazālī 2004, 98).

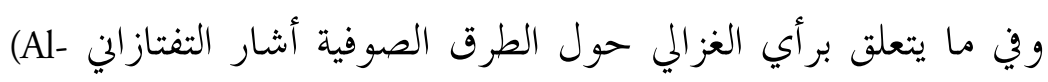

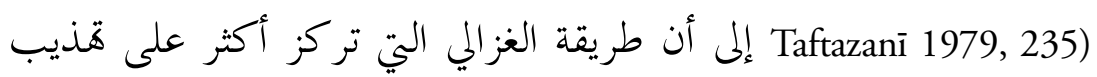


الأخحلاق الذي يتم عن طريق الرياضة الروحية تؤثر كثيرا في المتصوفين الذين جاؤوا بعده، والذين يطورون التصوف العملي في مؤسسات الطريقة. أما الطريقة الموجودة داخل مؤسسة الطريقة فإن تناولها لا يمكن فصله

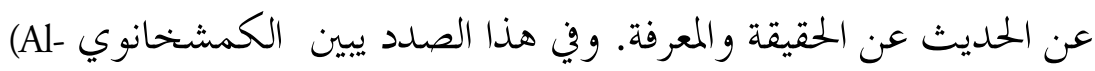

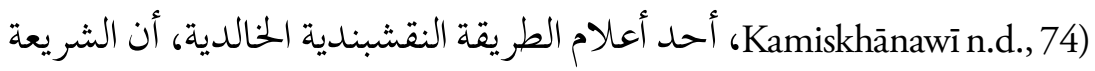
عبارة عن مطالب الأحكام، في حين أن الحقيقة هي نتيجة المعرفة الروحية؛ والشريعة تعززها الحقيقة كمأ أن الحقيقة تدعمها الشريعة. وبالتالي وفقا للكمشخانوي (Al-Kamiskhānawī n.d., 74) أن الشريعة تشير إلى الواجبات القائمة على الأوامر و النواهي، بينما الحقيقة تعتمد على الكشف الروحي.

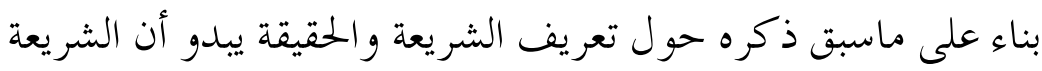
هي العمل الظاهري بينما الحقيقة هي نتيجته التي تتصف بالطبيعة الرو حانية. لذلك، فإن الحصول على النتيجة الرو حانية لابد من طريق يوصل الإنسان

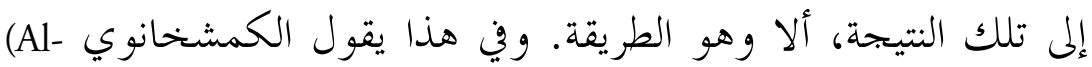
Kamiskhānawī n.d., 75) الطريقة هي ثمرة الشريعة. وعلى هذا، إذا استطاع شخص ما تنفيذ

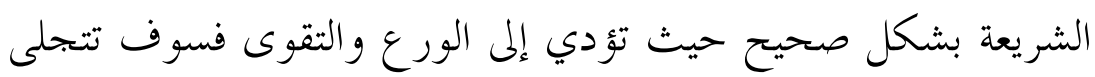
الطريقة بشكل تلقائي. و وإذا استطاع الإنسان ممارسة الطريقة بشكل صحيح فسوف يكتشف عنده أسرار الحقيقة. وبناء على ما وصفه الكمشخانوي من العلاقة بين الشريعة و الطريقة

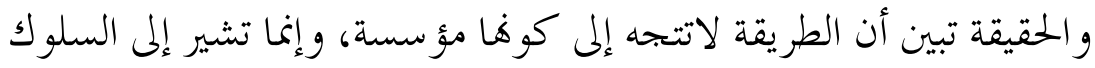

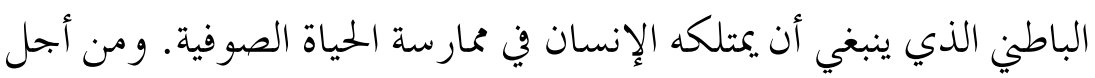

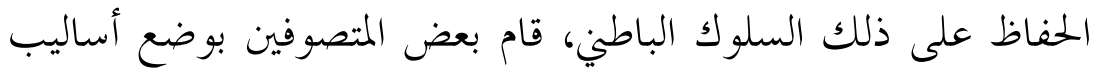
خختلفة للرياضة الصوفية تعتمد بشكل عام على طريقة الرياضة الروحية التي وضعها الغزالي (Al-Taftazanī 1979, 171). 
و بالمقارنة مع الآراء الصوفية المذكورة أعلاه فإن جوهر نظم الطريقة الذي وضعه الشيخ أحمد الرفاعي لا يختلف عنها عموما. كما يمكا يمكن ملاحظة ذلك من خلال شرو حاته كلما ذكر فيه مصطلح الطريقة، حيث

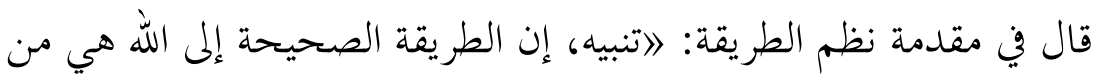
خلال تنفيذ الواجبات واجتناب المحرماته ويقول في مكان آخر: تنبيه واجب مكلف نتفنا شريعة \# يائكو علاكونى واجب عدوهى معصية

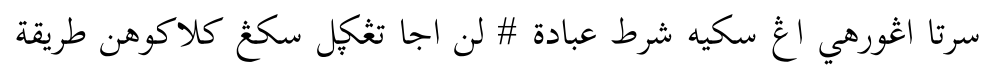
يائكو عبادة مارغ الله نجنى \# يين وس نتفى شريعة طريقة لكونى

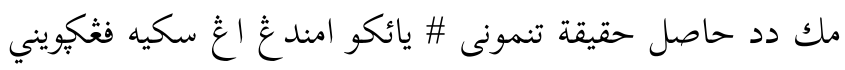

(Islam 2016, 228)

المعنى:

تنبيه، يجب على كل مكلف اتبا ع الشريعة \#\# بتنفيذ الو اجبات و اجتناب المعاصي

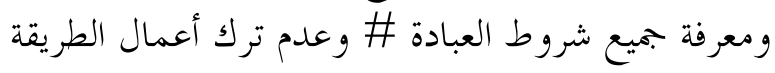
العبادة من أجل الله \#\# إذا توفر على الشريعة فله أن يمارس الطريقة

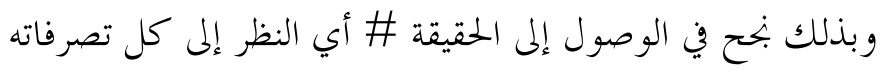

ووي ما يتعلق بالشريعة والطريقة والحقيقة، فقد أوضحت كذلك

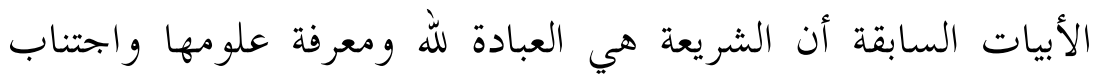
المعاصي. ووفي الوقت نفسه أن عمل الطريقة تشمله الشريعة، .كعنى أن

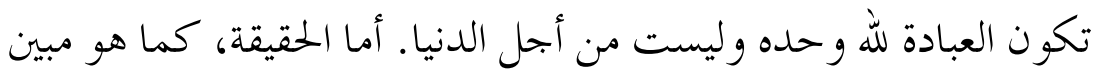
أعلاه، فهي موقف القلب الذي ينظر إلى جميع الأعمال بأهنا ملك للّ.

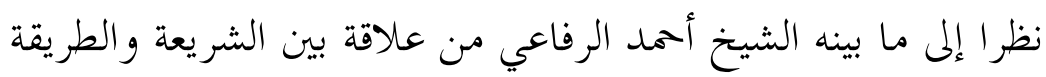

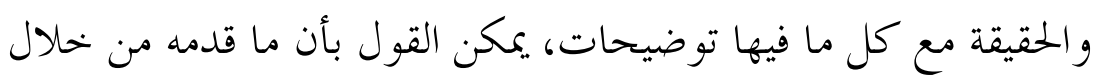
نظمه يتماشى مع ما بينه الكمشخحانوي. 


\section{مؤهلات شيخ الطريقة}

من الأمور الضرورية التي جرت في الخطاب الصوي بشكل عام

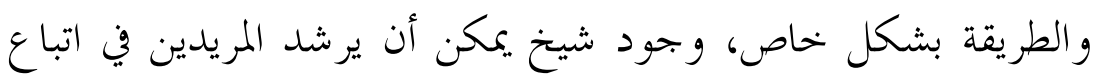

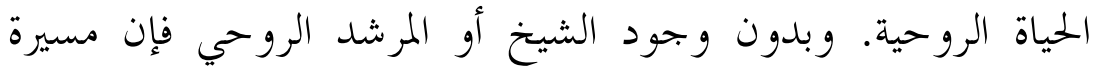

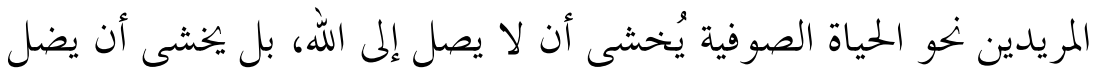

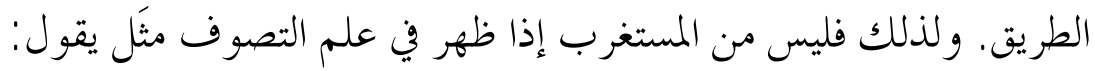

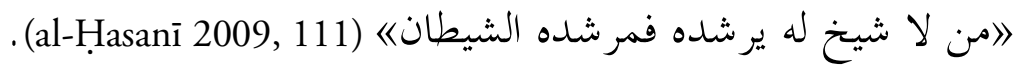

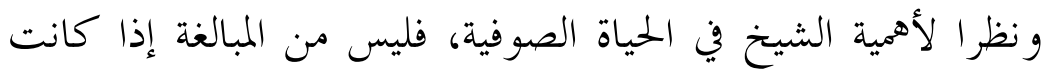

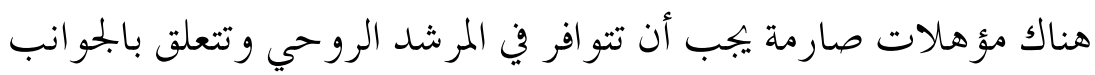

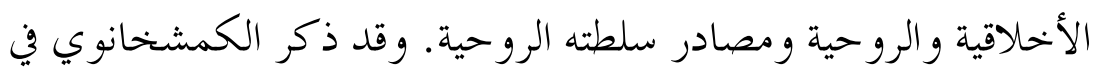

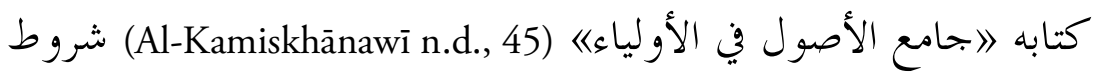

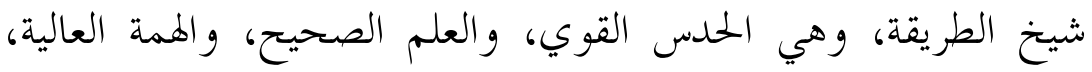

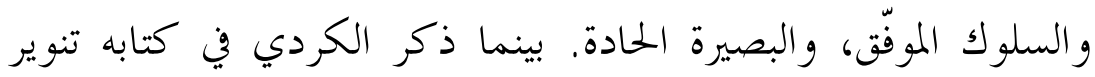

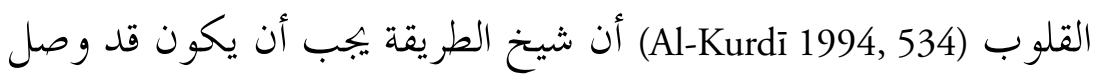

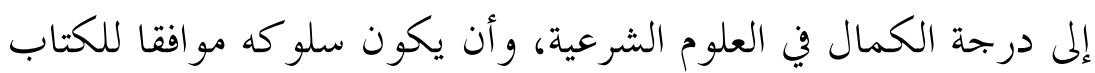

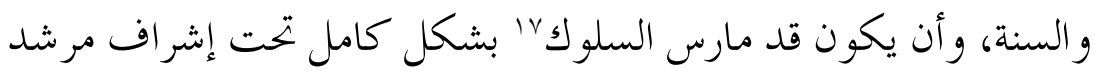

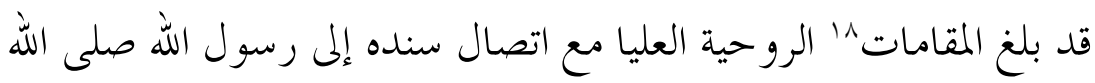

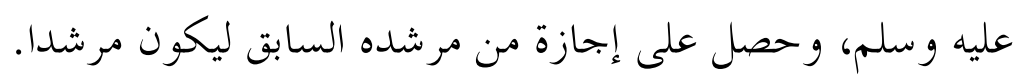

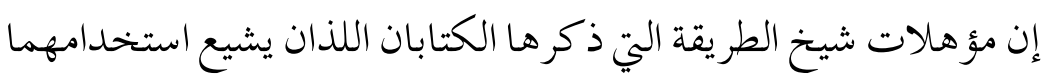

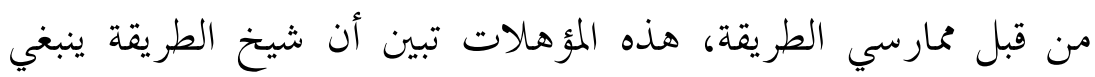

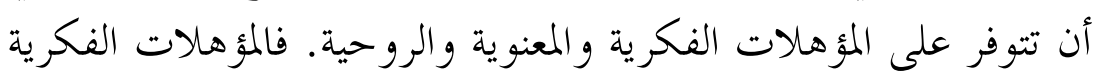

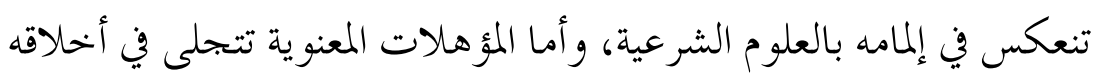

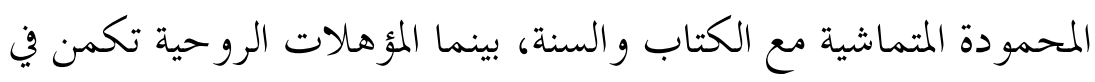

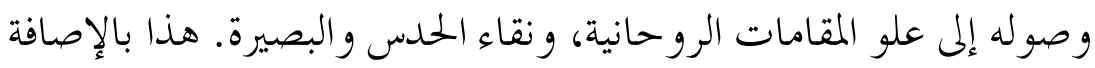


إلى حصوله على إجازة من شيخ الطريقة الذي قبله و الذي يتصل سنده إلى رسول الله. وبدون هذه المؤهالات فإنه لا يستحق لأحد أن يكوه يكون ئنس مرشدا لمن يريد ممارسة الحياة الروحية.

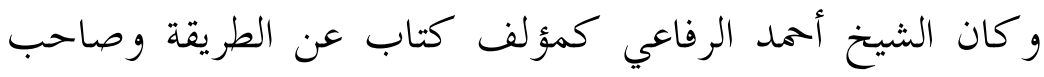
الفكرة المستقلة عنها، يبدو أنه مهتم كذلك بأهمية وجود شيخ للمريد الذي يمارس الطريقة. غير أن المؤهلات التي وضعها تختلف عن المه مهاتم المؤهلات

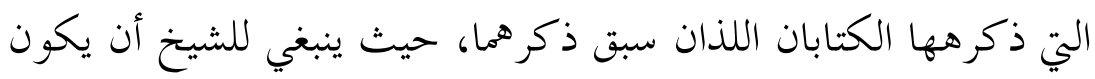
عالما عادلا، و وي ذلك يقول:

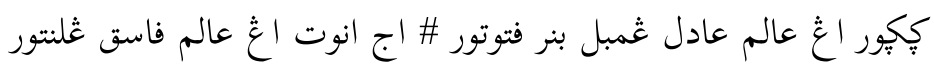
(Islam 2016, 123) التر مجة:

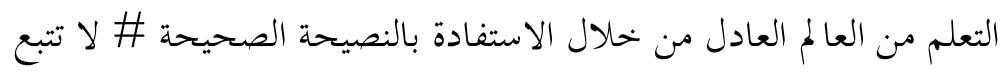

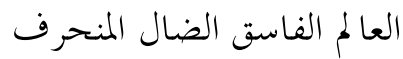
أوضح الشيخ أحمد الرفاعي من خلال البيت المذكور أعلاه أن تعلم

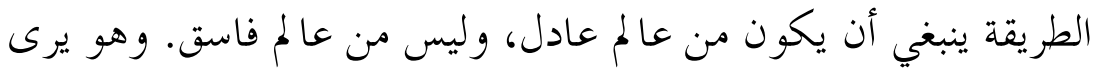

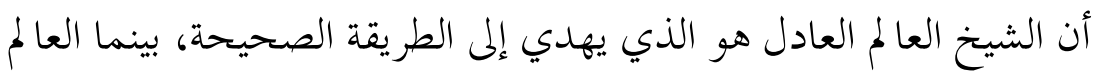
الفاسق هو المضلل. و إذا تأملنا الشروط التي وضعها الشيخ أحمد الرفاعي بشأن شيخ الطريقة يبدو أها لا تُتتخدم عادة في كتب الطريقة، وإنما كثر استخدامهما في وني كتب الفقه. فالعالم في الخطاب الفقهي يشير إلى اللقب الذي يحمله الشخص الذي يمتلك المعرفة ولو كانت مرتبطة مكسألة واحدة Al-Bayjūrī ) 1994a, 4) في حين أن العادل في الخطاب الفقهي لا يعين فقط العدالة في

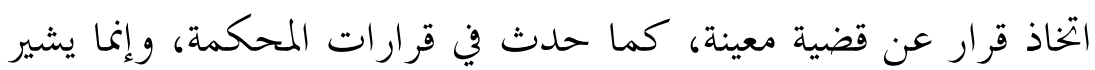
كذلك إلى الأخحاق الفردية للمسلم. ففي النكاح، على سبيل المثال، 
فإن أحد شروط صحته أن يكون الولي عادلا، بمعنى أنه لا يرتكب كبائر

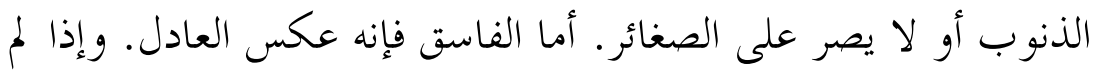

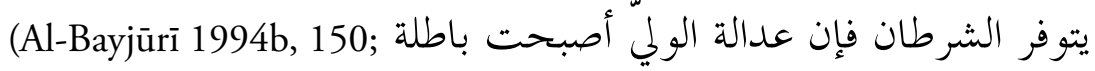
- Bakrī 1993a, 360) وبناء على ذلك فقد حدد الشيخ أحمد الرفاعي أن الشخص العالم

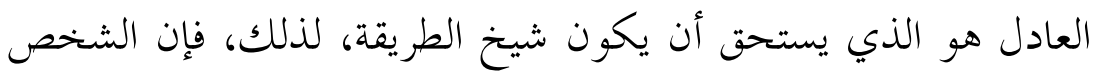

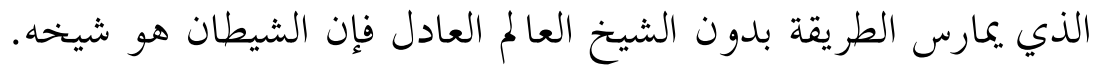

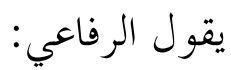

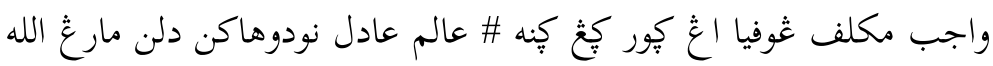

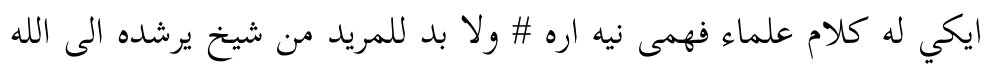

(Islam 2016, 198) الترجمة:

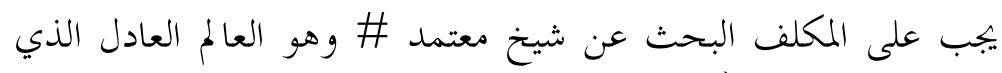
يرشده الطريق إلى الله هذا قول العلماء الذي ينبغي فهمه \#\# ولا بد للد للمر يد من شيخ يرشده إلى الله وقد أكد الاقتباس أعلاه أنه يجب على المكلف أن يبحث عن شيخ

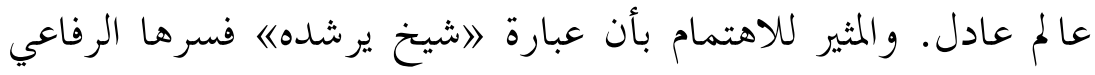

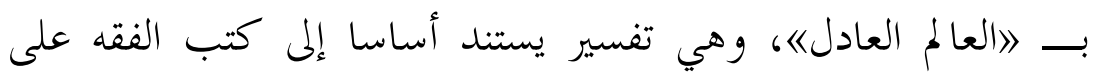

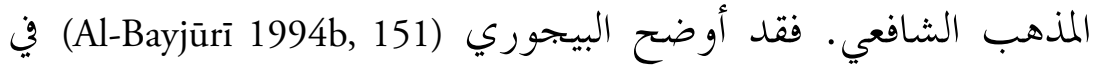

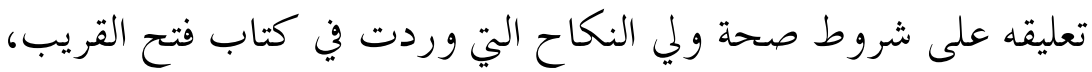

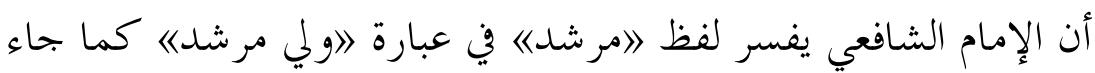

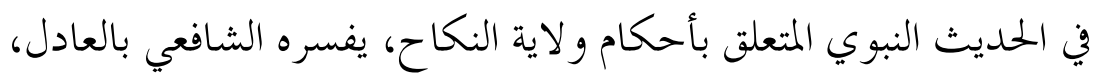

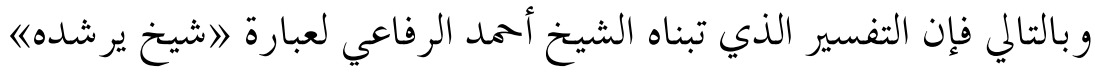
بأها 》العالم العادله يؤ كد قوة تأثير المبادئ الفقهية في تعاليم طريقته. 
وعلى الرغم من أن مؤهالات شيخ الطريقة التي وضعها الشيخ أحمد الرفاعي تختلف عن ما ورد في الكتابين اللذين مر ذكرهما، إلا أنه في ما يتعلق بضرورة وجود المرشد لمن يريد ممارسة الطريقة، يتبع ما هو شائع في

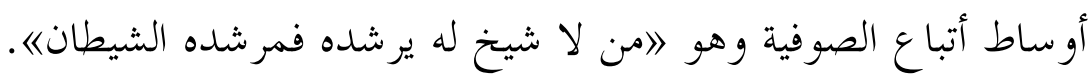
و في هذا الصدد يقول الرفاعي:

ايكى له كلام علماء فهمى دي وروه \# من لا شيخ له فالشيطان شيخه

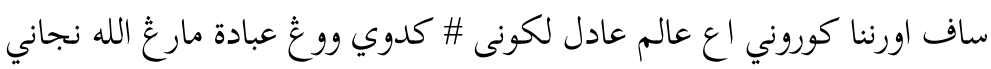

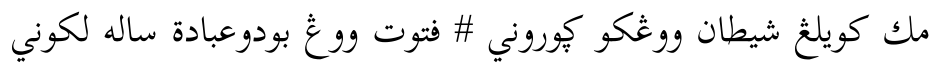

(Islam 2016, 198-99) التر جمة: لا بحعل العا لم الفاسق المشاغب شيخا \# إذا جعلته شيخا فإنك لن هتندي

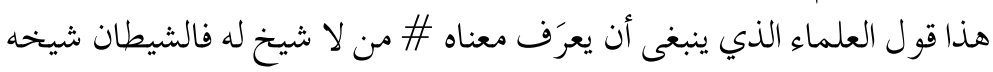

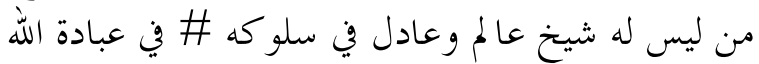

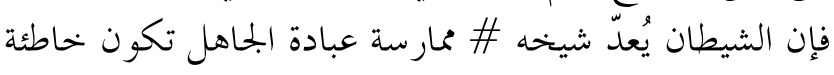
إن القول المأثور المذكور أعلاه نقله الشيخ أحمد الرفاعي من كتاب 》الحلممش《 لابن عطاء الله السكندري، وهو صوفي أصبح الزعيم الثالث للطريقة الشاذلية. وبالتالي فإن الرفاعي، في صياغة وجهات نظاء نظره بشأن

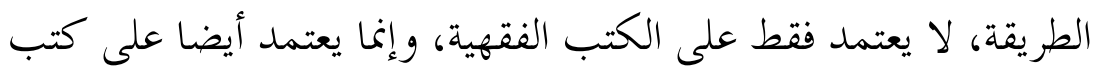

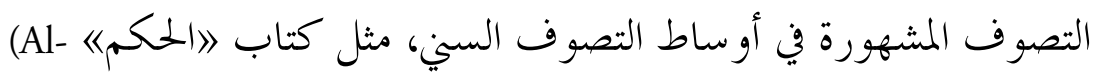
.Taftazanī 1969, 79-85)

\section{الطريقة والاحتجاج الاجتماعي}

ووعلى النقيض محا ورد عموما في كتب الطريقة حول ممارسة الطريقة فإن كتاب الطريقة الذي ألفه الشيخ أحمد الرفاعي يرتبط بشكل مباشر 
بالقضايا الاجتماعية والسياسية التي حدثث في عصره. لذلك، بالإضافة إلى إدراج المفاهيم الفقهية في تعاليم الطريقة، كما مر بيانه، فإن تعاليم الطريقة التي وضعها تختلف عن غيرها من التعاليم التي وردت في الكتب الأساسية حول الطريقة، وذلك في العلاقة العملية للطريقة مع الحاكم. وعلى هذا فإن أحد معايير الحقيقة لممارسة الطريقة، حسب رأيه، هو الابتعاد عن طبقة النبلاء، كما صرح بذلك بوضوح في الأبيات التالية: ايكوله طريقة نجا اغ الله ملهور \# انوت اغ علمونى الله كغ جوجور سكغ ككرفانى فرياي ال موغكور \# سكوسنى إِماني الله كنوي لوهور

(Islam 2016, 514) التر مهة:

تلك هي الطريقة التي تسعى إلى الله \#ت اتباع علم الله الحق

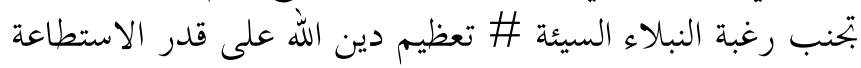

و قد أوضح الشيخ أحمد الرفاعي من خلال الأبيات السابقة أن الطريقة الصحيحة هي السعي إلى الله واتباع حقيقة علم الله. كما بين أن الطريقة الصحيحة هي الابتعاد عن رغبة النباء السيئة، ووفي الوقت نفسه لا لا بد من بذل الجهود لتعظيم دين الله. وهنا يبدو أنه قام بالمقابلة بين رغية طبقة النبلاء و الجهود إلى تعظيم دين الله. و كانت محاولة الرفاعي التي تقابل بين علاقة النبلاء و الدين في حد ذاتا تدل على الدينامية الاجتماعية التي حدثت في عهد الاستعمار، و التي تتعلق

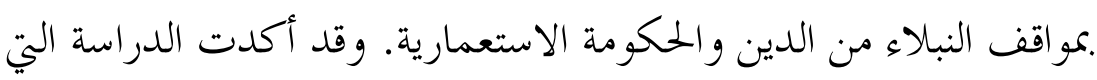

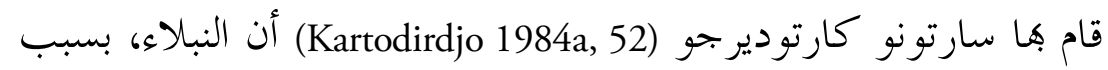
مخاوفهم على انطباع سيئ من قبل القوى الاستعمارية، كانوا يحاولون

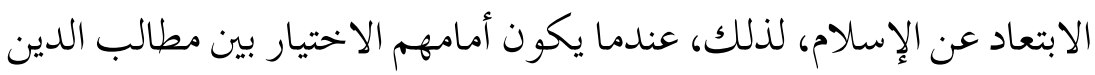

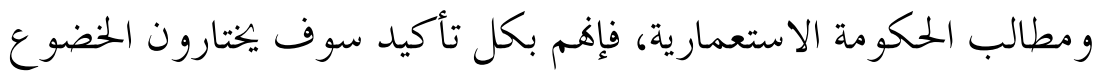




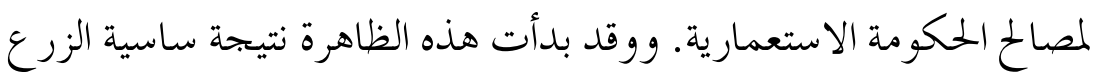
القسري التي انتهجتها الحلكومة الاستعمارية بعد انتصارها في حرب جاول ولماوا. و بفضل هذه الالتزامات من قبل هؤلاء النبلاء.مصالح الجلكومة الاستعمارية فإذم يكصلون على المكاسب الاقتصادية بجانب حصولهم على السماح لدخول الثقافة الاستعمارية (Lombard 2005, 103, 106). و قال الشيخ الرفاعي في أجزاء أخرى من نظم الطريقة، مؤ كدا في ذلك أن الطريقة الصحيحة ينبغي أن تتحقق في موقف الابتعاد عن طبقة النباء اءع:

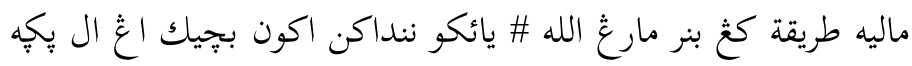

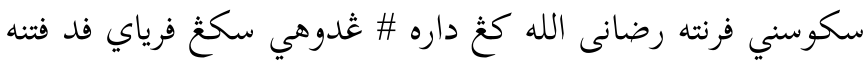

(Islam 2016, 515) التر مهة:

مرة أخرى، أن الطريقة الصحيحة إلى الله \# هي تنفيذ الأمر بالمعروف

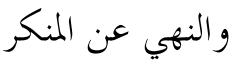
السعي إلى مرضاة الله بكل جدّ \# الإبكر الابتعاد عن النبلاء أصحاب الفتنة يظهر الاقتباس أعلاه أن الطريقة الصحيحة، بجانب الأمر بالمعروف

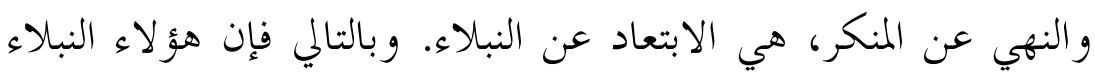
يعتبرون طرفا ينبغي اجتناهم من قبل ممارسي الطريقة. و السؤال الذي يطرح نفسه هنا، لماذا يجب على منىارسي الطريقة الابتعاد عن طبيقة النبالغء

وقد أوضح الشيخ أحمد الرفاعي من خلال نظم الطريقة السبب في ضرورة الابتعاد عن النبلاء و سلو كهم من قبل ممارسي الطريقة. وفيما يخص سلو كهم يقول الرفاعي: اور مكر گديني دوسا فرياي فرك كفر \# دنيا لعنة كث دسغاج اسه ملهر (Islam 2016, 159) 
التر.جة:

النبلاء يقتربون من الكفر ولا يفكرون في الكبائر \#\# يسعون عمدا إلى حب

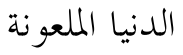

غالب فرياي ظالم تكبر فنثگه \# عندلكن منغ نغ دنيا سغگٍه

(Islam 2016, 385)

التر مهة:

غالبا ما يكون النبلاء ظالمين متكبرين \# يعتمدون على الانتصار من أجل سلطة الدنيا مالبا مان

وقد أوضح الشيخ أحمد الرفاعي من خلال الأبيات السابقة سلوك النبلاء المنحرف عن الشريعة، حتى لا يفكروا في كبائر الذنوب، كما

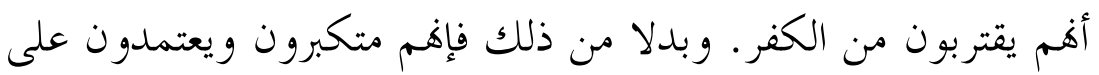
المناصب و السلطة في هذه الدنيا.

و في عصر الاستعمار كان الشيخ أحمد الرفاعي يعيش في منطقة ريفية

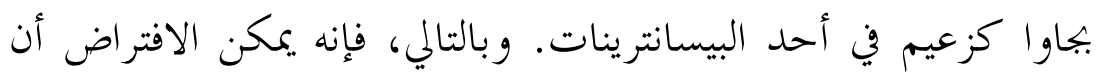

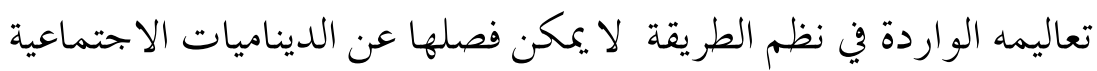
و السياسية في مناطق جاوا في عصر الاستعمار . و بناء على ذلك فإن تعاليم الطريقة التي وضعها والتي تدعو إلى الابتعاد عن طبقة النبلاء ينبغي أن

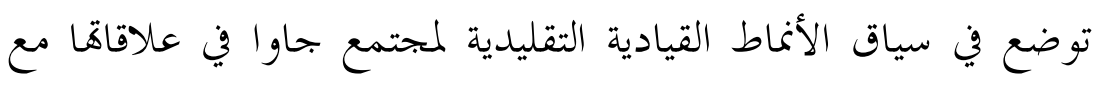
الحلكومة الاستعمارية.

ووي سياق هيكل القيادة التقليدية لمجتمع جاوا يوجد نمطان اثنين للنخب الاجتماعية التي تعتمد على التسلسل الهرمي الديني و النخبوي،

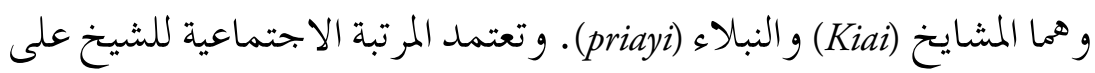

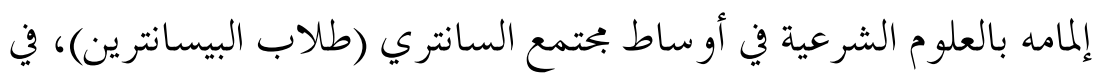

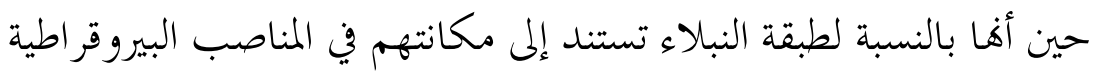


(Hisyam 2001, 211; Kartodirdjo, Sudewa, and Hatmosuprobo 1987, (54. وطوال الفترة الاستعمارية، كان وضع كل من هذين النوعين من النخبة الاجتماعية على طرفي نقيض، حيث كان النبلاء يميلون إلى إيجاد

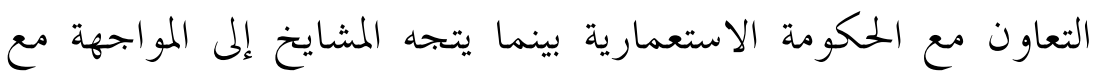
الحكو مة (Hisyam 2001, 212) و لا شك أن ما رآه الشيخ أحمد الرفاعي من خهلال شرو حاته الواردة في أبياته النظمية يتناسب مع الأوضاع الاجتماعية والامتيازات التي حصل عليها النبلاء من الحلكومة الاستعمارية والتي أثرت في أنماط

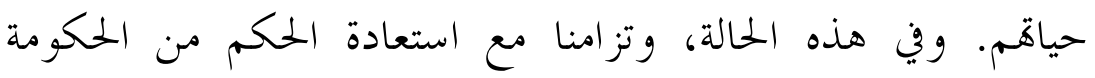
البريطانية إلى الحلكومة الهولندية، فقد تحول ريجنت (الأوصياء) وأهلهم وأقارهم الذين احتلوا مناصب حكومية إلى البيراقراطيين المحليين في (Kartodirdjo, Sudewa, and Hatmosuprobo نظام الإدارة الاستعمارية 1987, 18) وهم عبارة عن جماعة لا يرجع تشكيلها إلى العلاقات المهنية فحسب ولكن أيضا بسبب الروابط العائلية. لذا، فليس من المستغرب

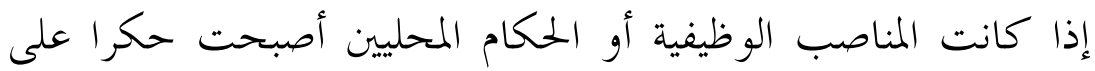

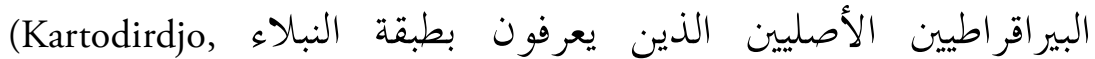
. Sudewa, and Hatmosuprobo 1987, 18)

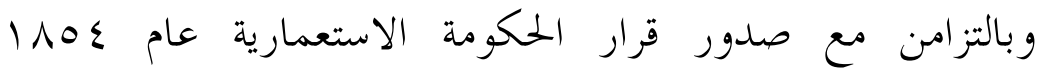
بشأن موقف الحكام المحليين، فإن مكانة النبلاء تزداد قوة باعتبارهم الأرستقراطيين الحاكمين الذين ينحدرون من فصيلة أصلية، كما يعتبر الوصي في هذه الظروف تجسيدا للقيادة التقليدية المحترمة (Sutherland) 1983, 42) و بالإضافة إلى ذلك، فإن صدور هذا القرار جعل منصب الوصي منصبا يمكن توريثه من جيل إلى جيل. و وإذا كان هناك منصب الوصي الشاغر فإن الذي يستحقه هو أبناء أو إخوة الأصياء الذين تركو إنيا 
هذا المنصب (Kartodirdjo, Sudewa, and Hatmosuprobo 1987, 19; . Sutherland 1983, 47) و نظرا لما يتمتع به هؤلاء النباء من الوضع الاجتماعي و السلطة، فليس

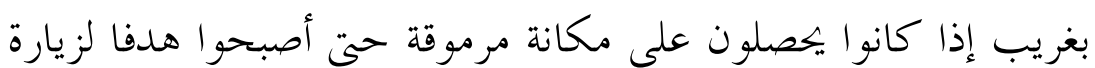
الأطراف التي تترقب المكاسب الدنيوية، بما فيها رجال الدين. ووفي هذا الصدد يقول الرفاعي: كيا تقصيري ستغه عالم فاسق ملهور \# ددي قاضي هنا غول سيبا ثلغسور

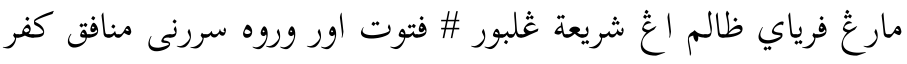

(Islam 2016, 448) التر مهة:

مثل هاون بعض العلماء الفاسقين الذين يسعون \#\# إلى أن يكونوا قضاة

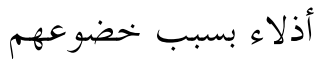
إلى النبلاء الظالمين الذين يدمرون الشريعة \#تهم فلا يعلمون أهم منافقون كفار ايكو فرتلا حرام نجها ملاهور \# مارغ ملاكو گاوي سيبا غلغسور

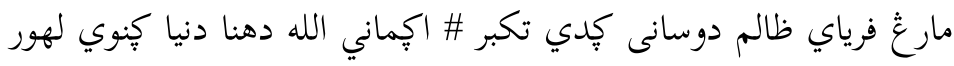
(Islam 2016, 464) التر مهة: من الواضح أنه حرام أن يحاول \# المشي متذلالا

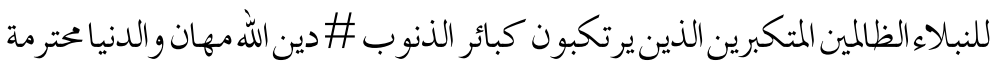
يقدم الشيخ أحمد الرفاعي في الاقتباس أعلاه تفسيرا عن الاحترام الذي حظي به النبلاء من قبل بعض الناس بما فيهم رجال الدين، وذلك

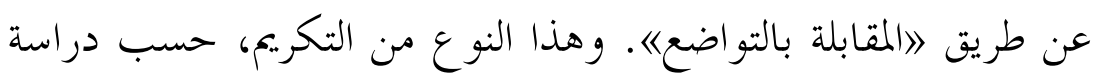
ساذر لاند (Sutherland 1983, 63)، عادة ما تتلقاه طبقة النبلاء العليا من الذين هم أدنى مرتبة، كما حصل ذلك في الزيارات المنتظمة التي قام هـا 
النباء الأدنى مرتبة إلى الأوصياء بناء على حساب السوق. وفي هذه المناسبة يقام حفل الترفيه بعرض رقصة روبججينج ronggeng مصاحبة بغاميالن، حيث يتحمل النباء تكاليف هذا الحفل. و لم يقتصر لزوم تلك الزيارات على حساب السوق، ولكن أيضا في مناسبات الأعياد مع مراسم خاصة ينبغي القيام بها، من بينها ارتداء الملابس المحددة والدخول إلى القاعة الأمامية Pendapa بطريقة القرفصاء،

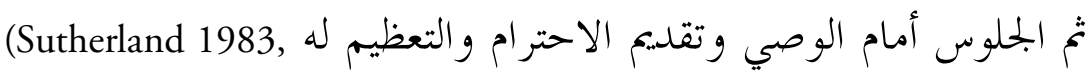

علاوة على ذلك، يبين الرفاعي من خلال الأبيات السابقة سلوك النبلاء الذين يفتخرون بثرواتم الدنيوية، كما ظهر ذلك في الترف ترفي الذي تعود ملكيته إلى عائلة الوصي، بحيث قام الوصي بعرض برونم ثرواته ورغبته في الكرم بشكل خاص في مناسبة تنصيبه كوصي من خلال تقلديم و جبات الطعام و الترفيه للأوربيين المحليين، و الصينيين، و النبلاء، ثم عامة الناس (Sutherland 1983, 61). و لم تقتصر الحفلات الهادفة إلى إظهار هذا

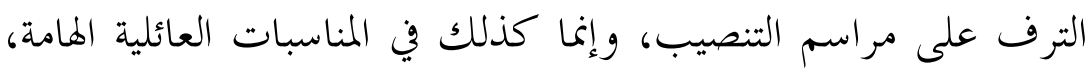
مثل حفل الزفاف والختان والأحداث المهمة التي يمر بها الوصي خهابل فترة ولايته، مثل قبول لقب جديد وشهادة تقديرية، والنجاح في تحقيق سنة الخدمات الرائعة (Sutherland 1983, 62). و كذلك يتعين على الوصي تنظيم حفلات على النمط الأوربي استقبالا للأحداث الهامة، مثل عيد

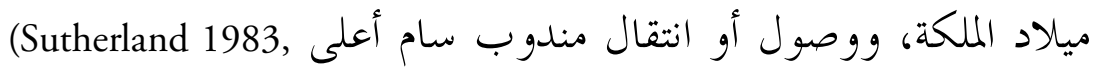

ولا شك أن الحفلات التي يقوم بها النبلاء والتي يتخللها كثير من الفعاليات الترفيهية جذبت رغبة الناس في المجئ إليها، غير أها في نظر الشيخ أحمد الرفاعي يمكن أن تغري الناس لنسيان ما هو حلال وما هو 
حرام. لذلك فليس من المستغرب إذا وجهه انتقاداته إلى تلك الحفلات

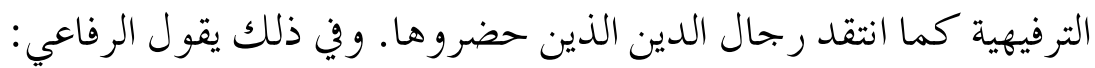

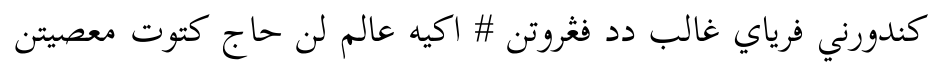
سكغ حرام مجلس اور سنغكرن \# اكيه عالم اور نتور اغ ال ال فثفوسن

(Islam 2016, 426) الترجمة: حفل النبلاء غالبا ما يجذب الانتباه \# كثير من العلماء والحجاج يشاركون في المعاصي لا يبتعدون عن كل ما هو حرام في المجلس \# كثير من العلماء لا يوضحون سوء الخدعة

في الاقتباس أعلاه، يرى الشيخ أحمد الرفاعي أن تلك الحفلات التي

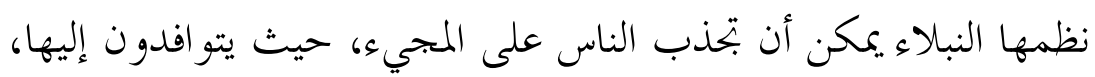

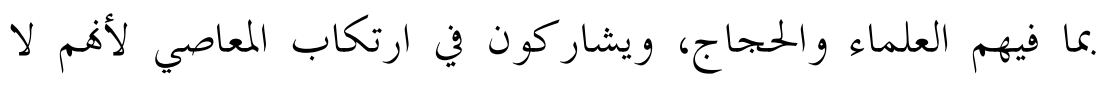
يقولون الحقيقة. و بالإضافة إلى نمط الحياة المرتبطة بالعلاقة بين الأعلى والأدنى في طبقات

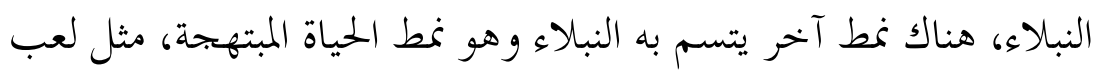

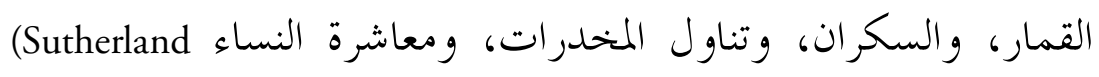

وهذه الأنماط من الحياة التي تظهر الترف وتساهل المتعة، يبدو أها بعيدة

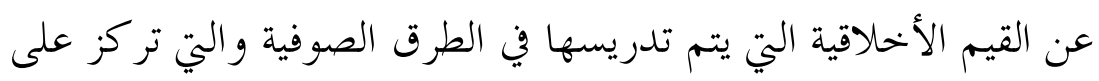

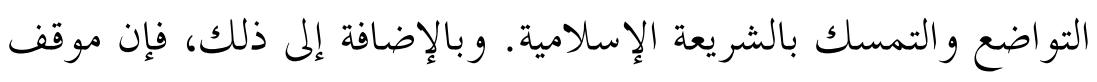

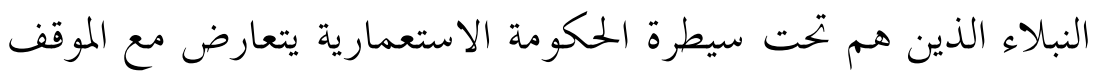

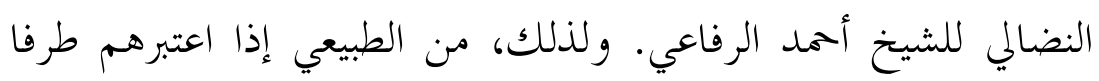

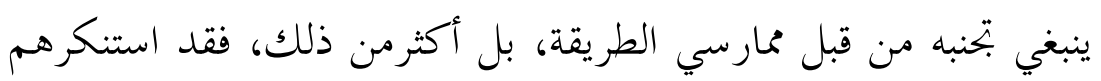


على أهم مروجو القذف، و مدمروا الشريعة وغير ذلك من الانتقادات القاسية التي يمكن العثور عليها في نظم الطريقة. و بناء على ما و صفه الشيخ أحمد الرفاعي من قضية الطريقة يمكن القول إن الطريقة التي نشرها هي طريقة بمعنى موقف أخلاقي ينمو من خحلال

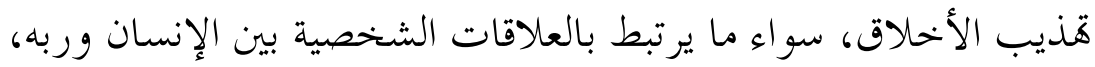
أو في سياق العلاقات الاجتماعية. لذلك، فليس بغريب أن يكون السلوك

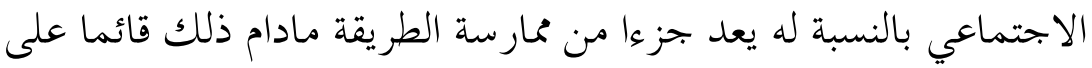
أسس من الشريعة و الأخحلاق.

\section{العالم العادل في الحركات الاحتجاجية الاجتماعية بجاوا}

كما سبق ذكره أن تغلغل الاستعمار لمستعمراته له تأثير في التغيرات الاجتماعية والثقافية في مناطق جاوا. و وعلى مستوى النخبة فإن هذه التغيرات بتحلت بوضوح في تراجع ولاء النخبة الأرسطقر اطية التقليدية

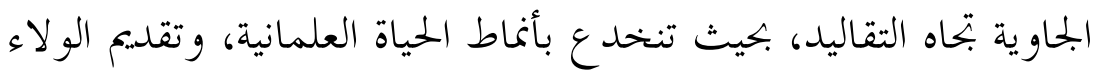

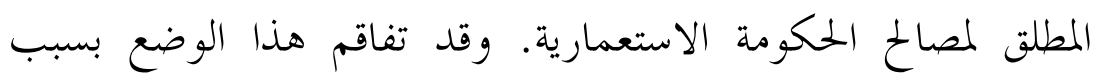
انقسام زعماء الدين في مواقفهم من الحكومة الاستعمارية بين الموالين

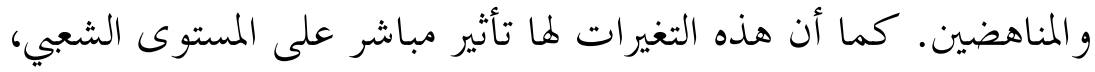
بحيث يواجهون أعباء الحياة الثقيلة على نحو متزايد بسبب التبر السياسات و اللوائح القمعية التي وضعتها الحكومة الاستعمارية ضد الفلاحين الجاويين

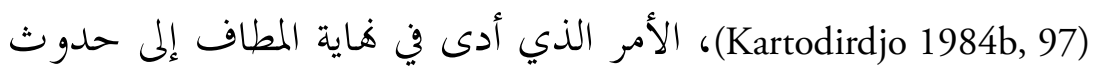

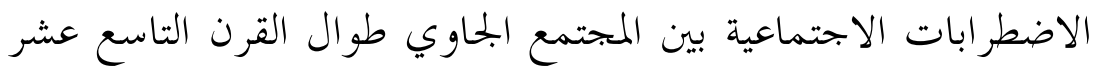
الميلادي (Kartodirdjo 1984b, 12) و وي خضم هذه الاضطرابات الاجتماعية، فإن التطلعات إلى عودة الماضي، حسب ما هو سائد في النظام القيمي عند المجتمع الجاوي 


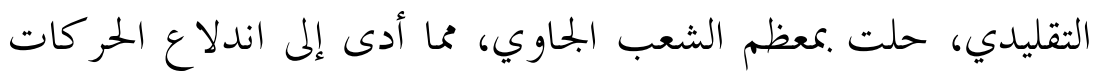

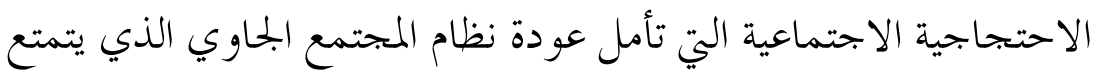

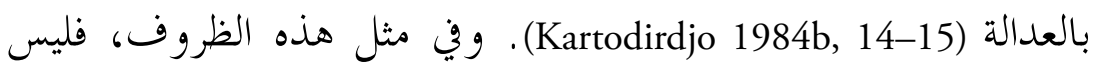

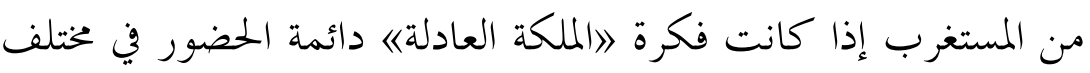

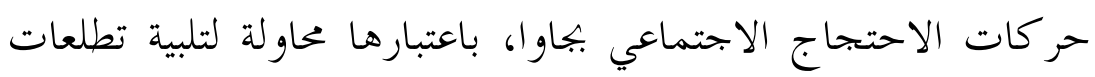

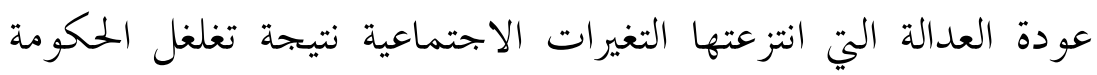

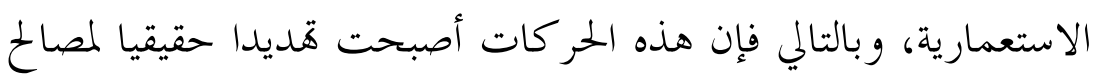

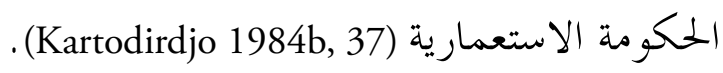
ويلاحظ كارتودرجو (Kartodirdjo 1984b, 53) أن بتسيد تلك كانك الحركات كشف عن الخصائص الأيديولوجية التي يصعب تمييزها تمييزا

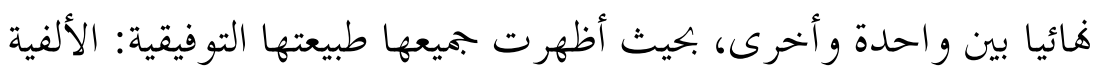

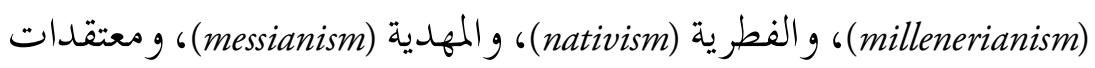

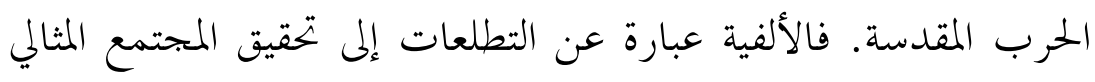

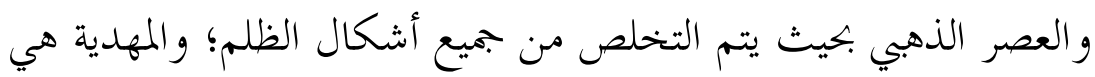

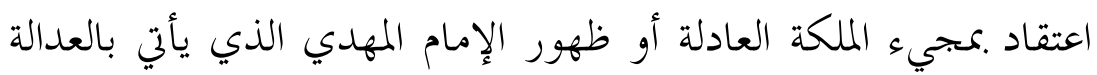

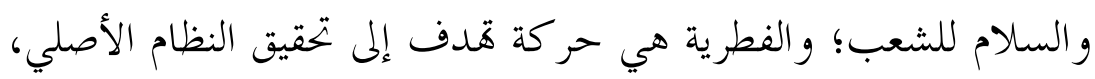

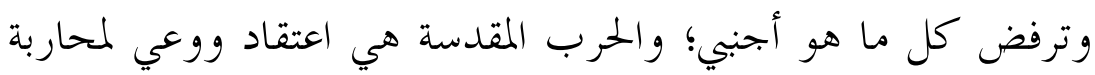
الكفار (10-10) و الطبيعة التوفيقية الموجودة وراء فكرة 》الملكة العادلة) (المهلدية)

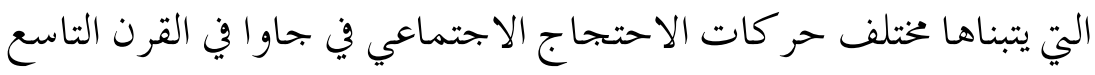

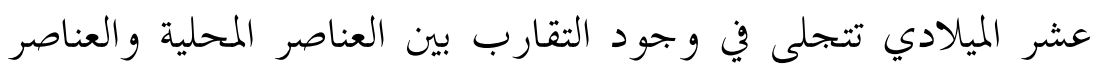

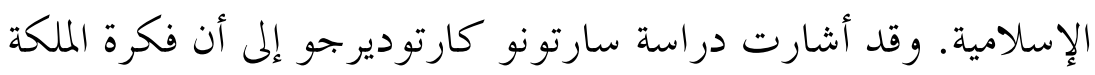

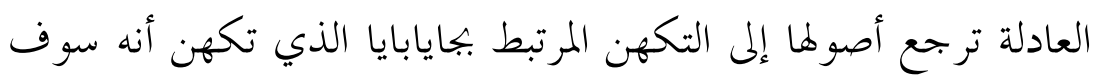

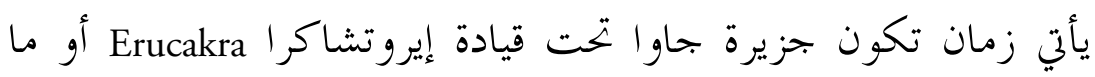


يعرف بالملكة العادلة بكل ما يعمها من العدالة والازدهار. وومع ذلك، قبل أن يتحقق هذا الزمان فإن مناطق جاوا سوف تتعرض للكوارث الطبيعية والأوبئة التي تنتشر في كل مكان، و كذلك الانغطاط الأخلاقي (Kartodirdjo 1984b, 55-56). وفي وسط الظروف المليئة بالقمع الذي مارسته الحكومة الاستعمارية، فليس من المستغرب إذا كان كثير من قادة الحركات الاحتجاجية الاجتماعية والمقاومة ضد حكم الاستعمار يعرّفون فئه

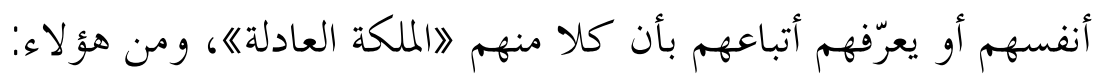
بانيمباهان إيروتشاكرا Panembahan Erucakra، ابن أمابخكورات الأول

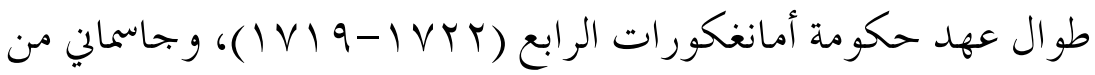

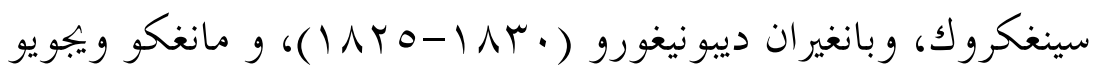

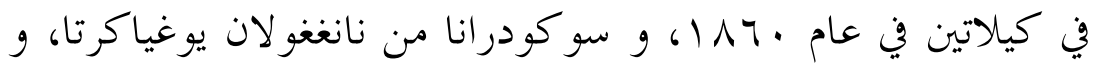
إمام سو جانا من سوراكرتا (Kartodirdjo 1984b, 18). و فيما يتعلق بالعناصر الإسلامية، أظهرت الدراسة التي قام بها سارتونو كارتوديرجو (Kartodirdjo 1984b, 59) أنه على الرغم من أن التكهنات المتعلقة مكجيء الملكة العادلة هي في الأساس ليست من التعاليم الإسلامية

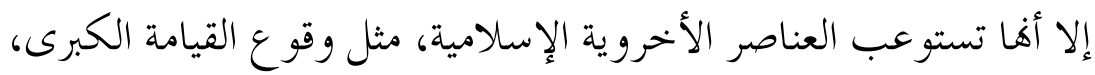
وظهور الإمام المهدي الذي يقع بعد بجيء الملكة العادلة وقبل وقوع القيامة.

و من ناحية أخرى، فإن دخول العناصر الأخروية الإسلامية التي تتجلى العه في ظهور الإمام المهدي قبل وقوع الساعة، كل ذلك يؤكد دخول دخول التقاليد المهدية الإسلامية في فكرة الملكة العادلة. و كما هو معروف إن أن في التقاليد الإسلامية اعتقادا أنه سوف يأتي قبل وقوع الساعة زمان يكون فيه قائد يتمكن من تحقيق العدالة بعد أن يكون مليئا بالظلم. ويعرف هذو هذا القائد في العقيدة الإسلامية بالإمام المهدي (21-Wahid 1999, 120). 
ونظرا لقوة أيديولوجية الملكة العادلة التي تتبناها مختلف الحركات الحات الحتات

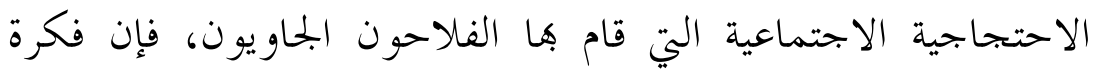

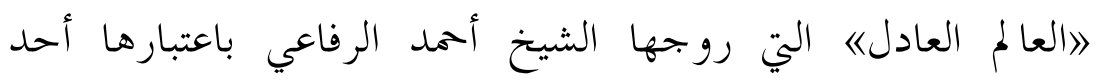

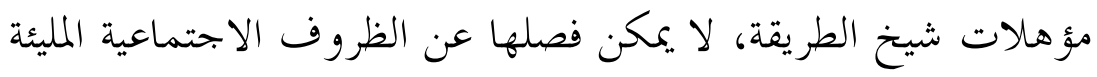

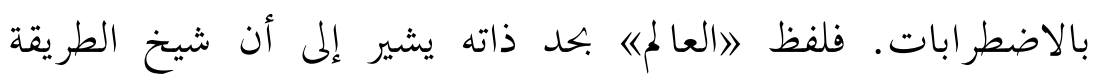

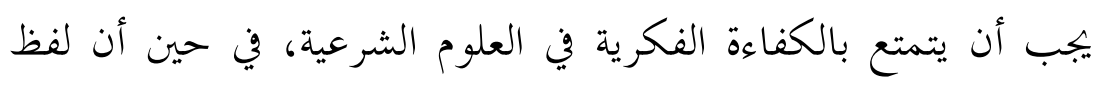

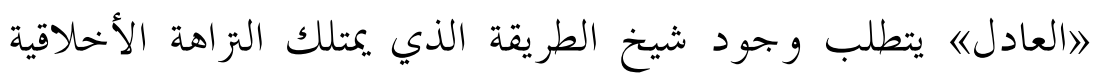

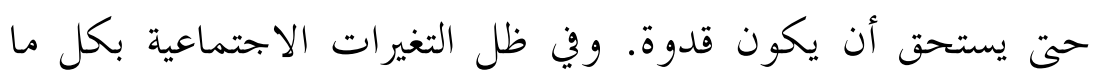

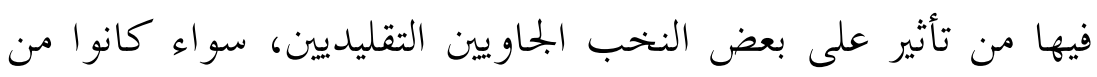

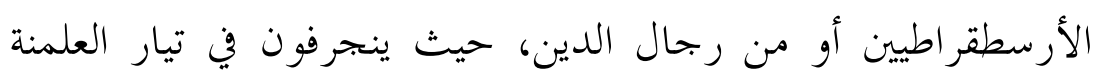

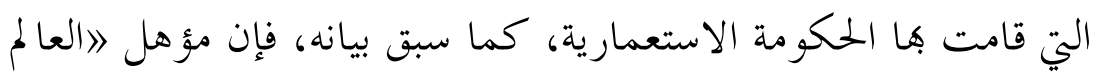

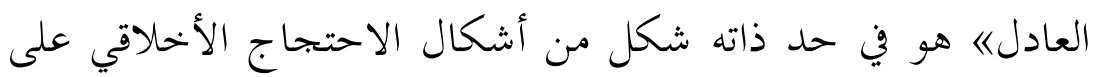

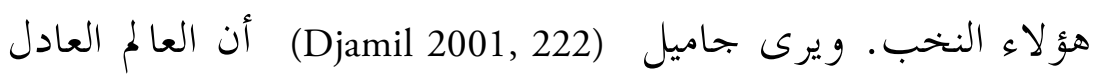

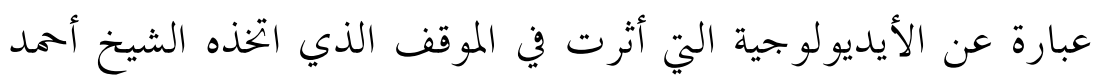

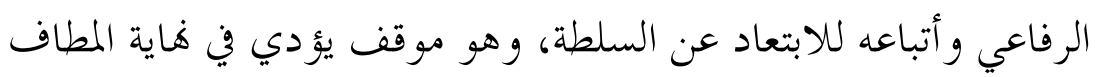

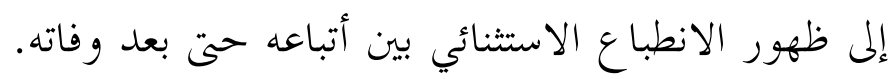

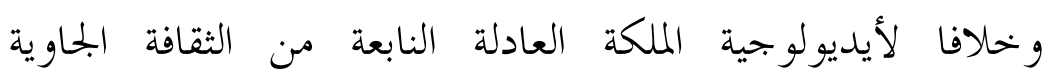

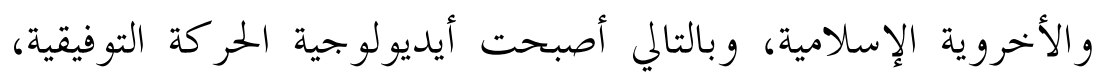

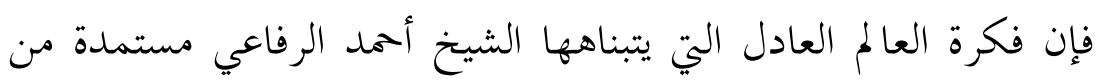
تعاليم الشريعة الإسلامية، وعلى وجهه التحديد من الأحكادي التحام الفقهية.

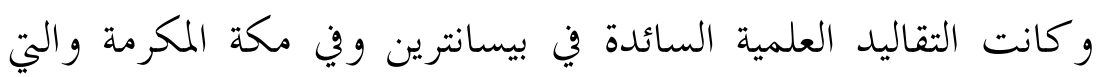

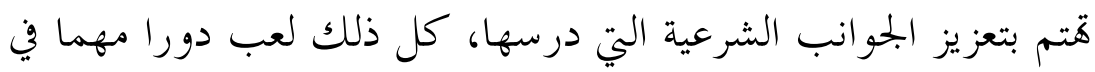
ظهور الفكرة، كما أن السبب في اختياره لهذه الفكرة (العالم العادل)

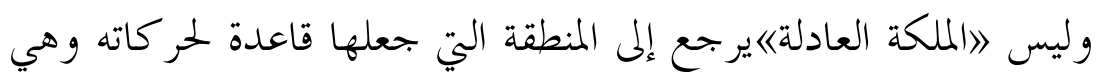


بيكالونغان. وقد لاحظ سارتونو كارتوديرجو (Kartodirdjo 1984b, 70) أن بيكالونغان هي قاعدة للسانتري (طلاب البيسانترين)، حتى لا يمكن.

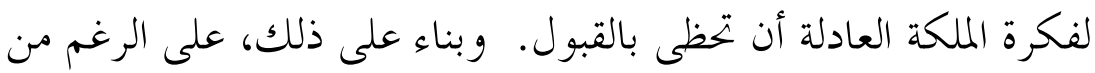
أن العالم العادل في نظر الشيخ أحمد الرفاعي من مؤهلات شيخ الطريقة إلا أن الدينامية الاجتماعية و السياسية التي حدثت بجاو ا، بكل ما فيها من الحركات الاحتجاجية الاجتماعية، تؤ كد أن العالم العادل ليس فقط من مؤهلات شيخ الطريقة ولكن أيضا أساس الحر كة الاحتجاجية ضد النظام الاجتماعي الذي يعاني الانحطاط الأخحلاقي نتيجة التغيرات الاجتماعية التي تأثرت بتغلغل الحلكومة الاستعمارية. و من ناحية أخرى، فإن قوة الأسس الفقهية المؤثرة في فكرة العالم العادل كأحد مؤهلات شيخ الطريقة تؤثر في الحركات الاجتماعية التي يتبناها الرفاعي وسط الظروف الاجتماعية المضطربة التي ضربت مناطق جاوا في القرن التاسع عشر • و خلافا للحر كات الاحتجاجية الاجتماعية الموجودة

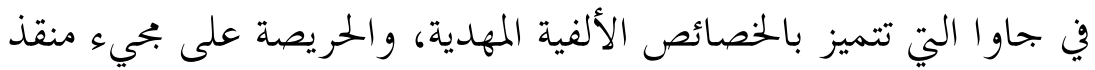
وعصر ذهبي في منطقة جاوا، بعد أن كانت تعاني الكوارث الطبيعية

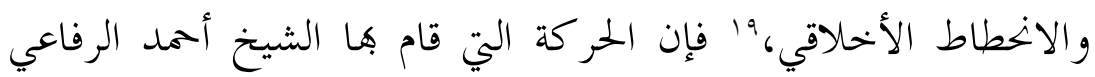
تركز أكثر على الإصلاح الاجتماعي والأخلاقي للنظام الاجتماعي الذي يرى أنه منحرف عن الشريعة الإسلامية. لذلك فليس من المستغرب إذإِ كانت الحجة التي استخدمها في مقاومة مختلف النظم الاجتماعية التي

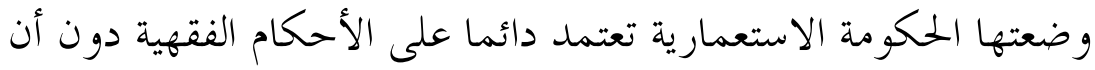

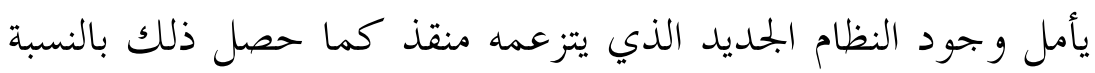

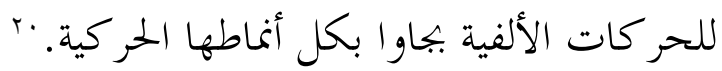
وعلى الرغم من أن العالم العادل يظهر دائما في نظم الطريقة باعتباره مؤهل شيخ الطريقة والشخصية البارزة التي يحتذى بها من قبل المجتمع، 
إلا أن ظهوره يقتصر على كونه المؤهل الفكري والأخلاقي الذي ينبغي

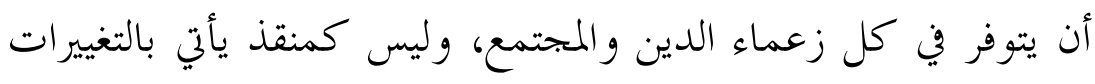
الثورية لمجتمع جاوا.

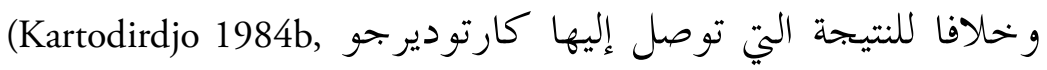

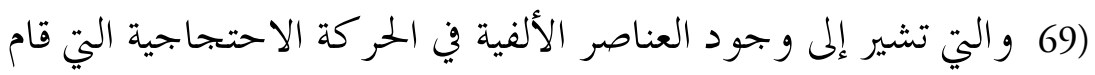

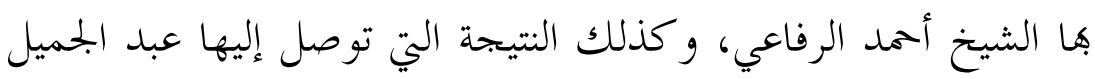
(Djamil 2001, 237)

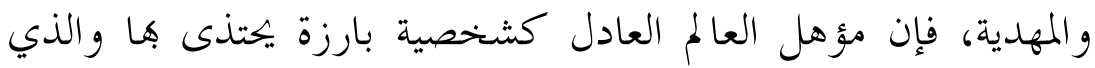
وضعه الرفاعي بعيد عن العناصر الألفية والمهدية.

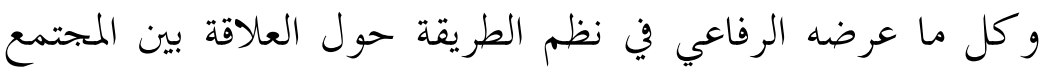

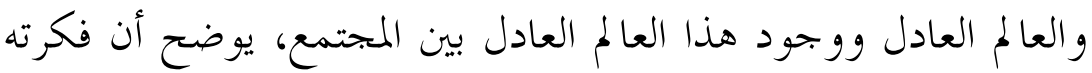

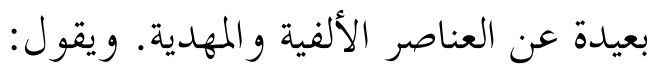

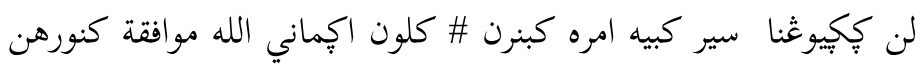

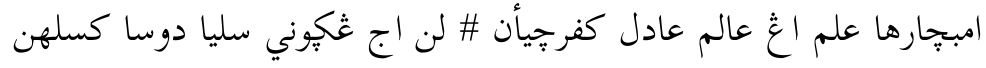

إنفأنا اغ عالم عادل سليا فتوني \# لمن ان عالم عالم عادل رورو سليا علمني

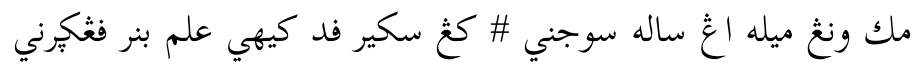

لمن ساله سوجني لوه اكيه فتوتور \# مك واجب إعب اعتماد ارف ملهر

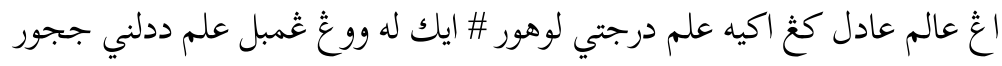

(Islam 2016, 211) الترجمة:

اعتصموا جميعا في البحث عن الحقيقة \# بدين الله وفقا لما تم تعليمه

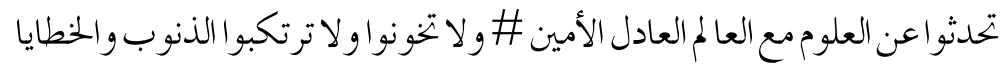
لا حظوا فتاوى العالم العادل المختلفة \#\# إذا كان هناك عالمان عادلان تختلف علومهما 
يجوز اختيار أحدهما \#\# إذا كان كل منهما متساويا في العلوم وصحيحا في الدليل

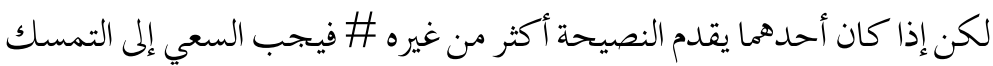

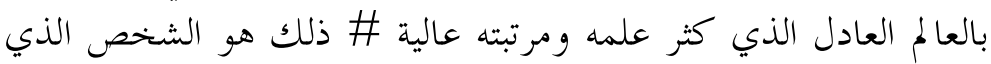
يؤخذ منه العلم بطريقة صحيحة

يبين الشيخ أحمد الرفاعي من خلال الأبيات المذكورة أعلاه أن العالم العادل هو شتصية بارزة تتمتع بالكفاءة الفكرية في بحال العلوم الشرعية حتى يستحق إصدار الفتاوى الدينية. لذا، يجب على عامة الناس اتباعه. وإذا كان في المجتمع عالمان عادلان، و حصل بينهما خلاف في الفتاوى، إنسا، فيمكن للمجتمع أن يختار واحدا منهما إذا كانت الأدلة التي يعتمد عليها كل منهما متساوية في القوة، ولكن إذا كان أحدهما أوسع علما من الآخر يتعين على المجتمع اتباعه دون الآخر.

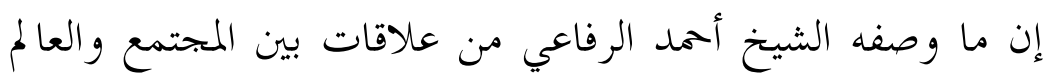
العادل في قضية الفتاوى الدينية يبدو أنه مستوحاة من المسائل الخلافية المتعلقة بالفتاوى الفقهية والتي حصلت بين الفقهاء، وما يجب على إنى المسلمين فعله. حيث يو جد في الفقه الشافعي أحكام تنص على أن المسلم الذي يحتاج إلى الفتوى عليه أن يستفيت العالم العادل الذي عرفت قدرته

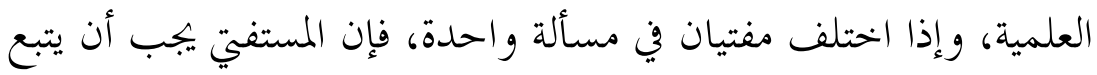
من هو أكثر علوما، ولكن في حالة عدم معرفة من هو أعلم يبجوز له الأخذ

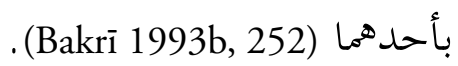

و اعتمادا على هذه المقارنة بين ما وصفه الرفاعي وما نص عليه الفقه

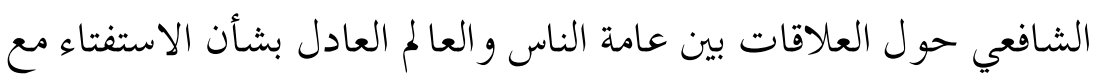

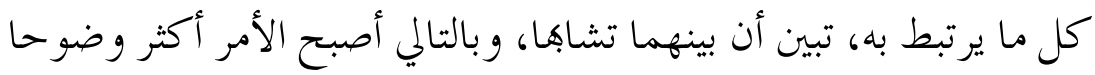
بأن فكرة العالم العادل التي جاء بها الرفاعي مستندة إلى الأحكام الفقهية. 
وبعبارة أوضح أن الشخص الذي يجب أن تؤخذ فتواه وفقا للأحكام

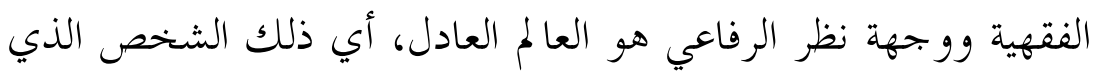
يتمتع بعلو قدرته الفكرية وأخلاقه.

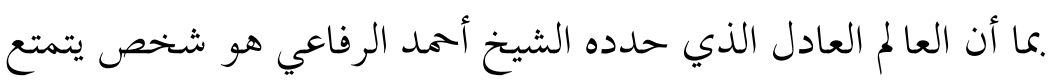

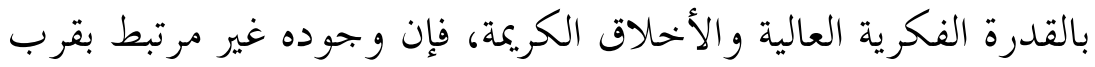

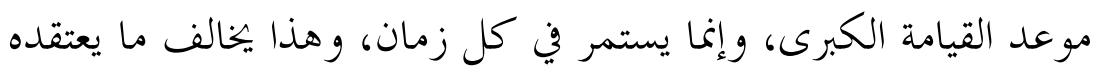

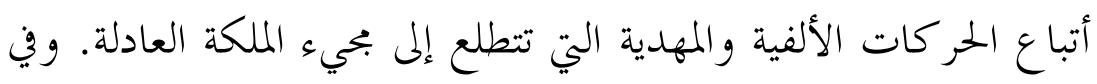
هذا السياق يقول:

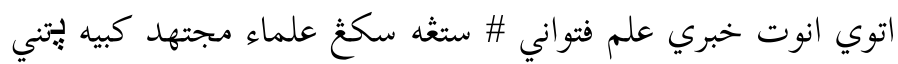

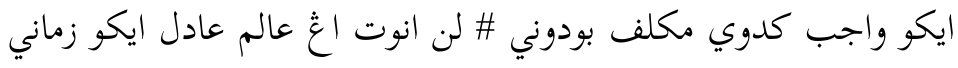

(Islam 2016, 405) الترجمة:

أما اتباع خبر العلم الذي يفتيه \# بعض العلماء الذين لا شك أنم من المجتهدين فيجب على كل مكلف جاهل \# \# اتباع العالم العادل في زمانه

بناء على ما وصفه الشيخ أحمد الرفاعي المذكور أعلاه تبين أن العالم

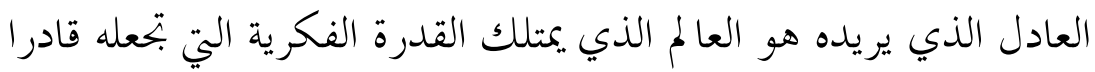

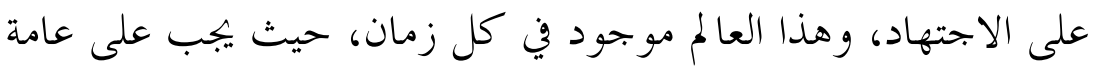

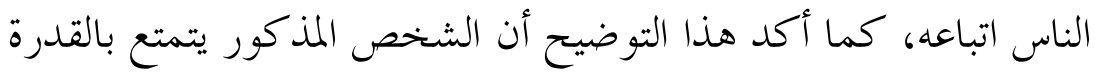

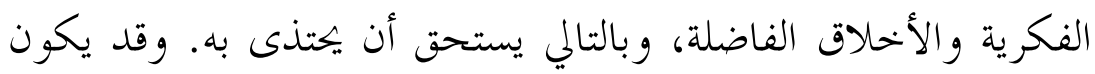

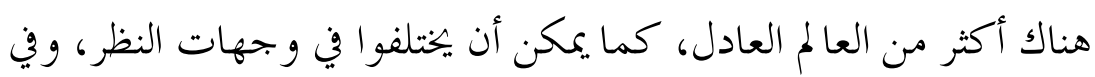
هذه الحالة يجوز لكل مسلم أن يتبع من تطمئن إليه نفسه.

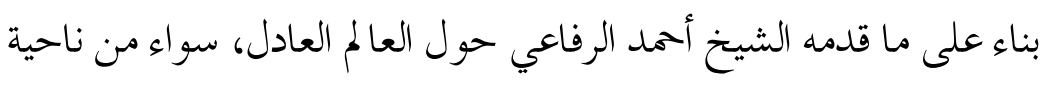

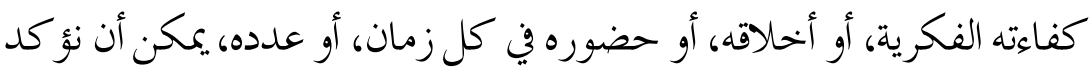
أن هذه الفكرة نابعة من التعاليم الفقهية بعيدة عن العناصر الألفية والمهلدية المنتظرة. 


\section{خلاصة}

إن نظم الطريقة الذي ألفه الشيخ أحمد الرفاعي في منتصف القرن

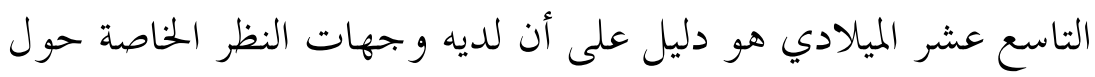

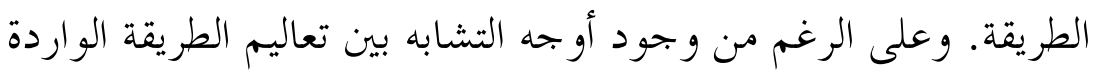

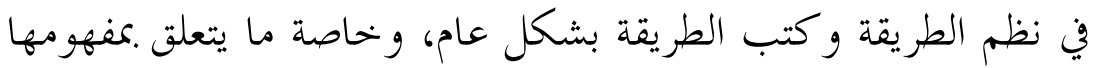

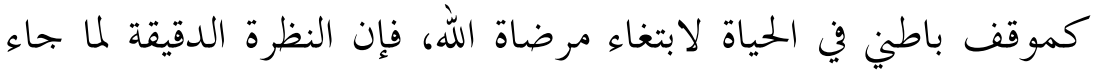

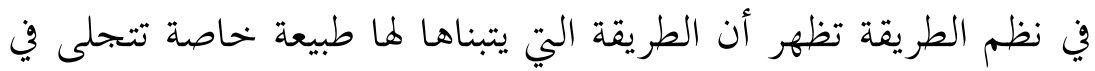

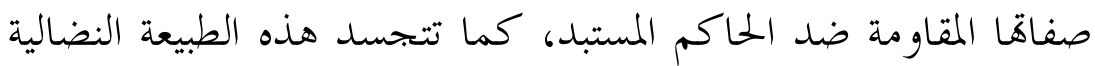

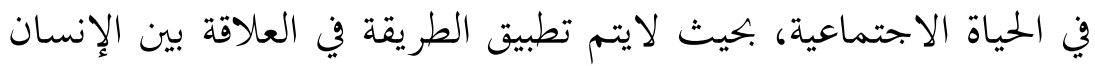

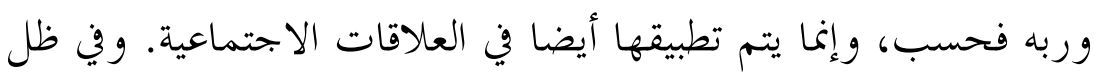

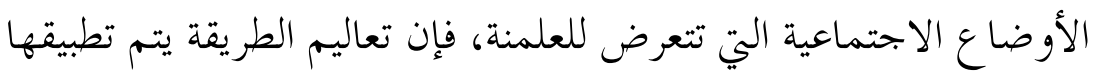

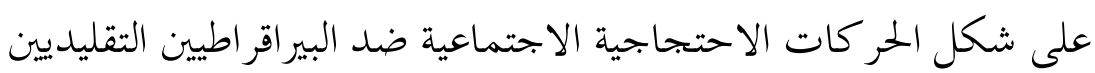

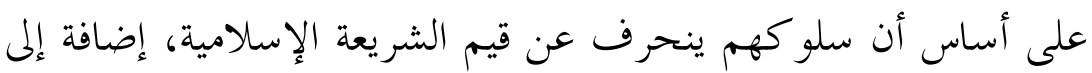

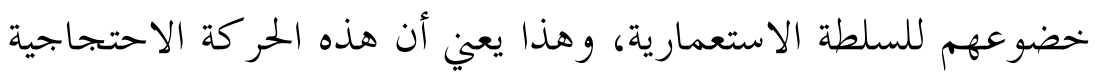

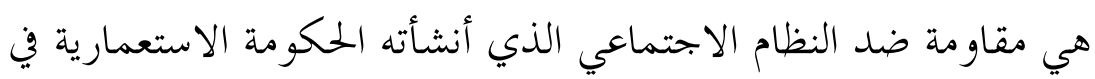
مستعمر اتها.

أما الخاصية الأخرى لهذه الطريقة فهي اعتمادها على الأسس الفقهية

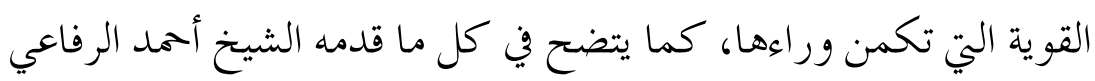

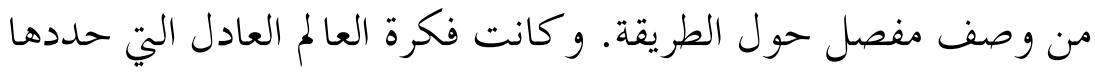

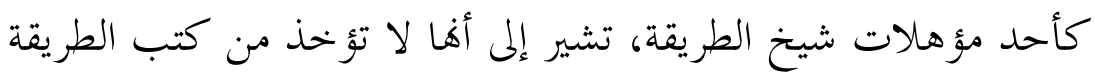

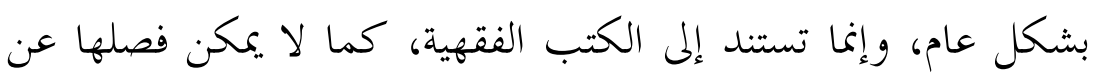

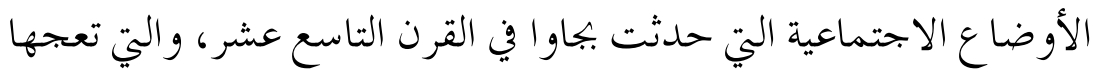

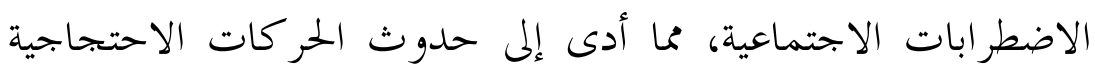

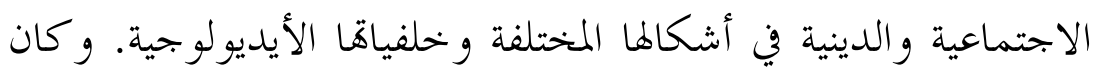




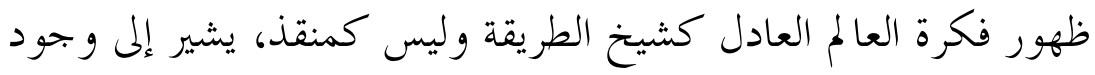

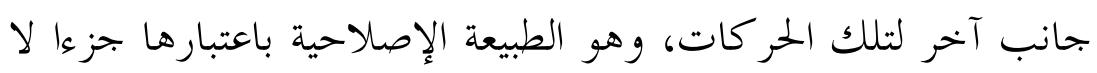

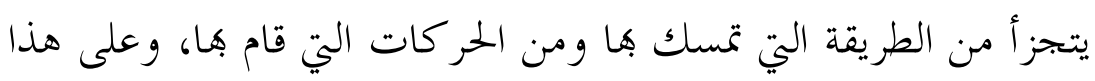

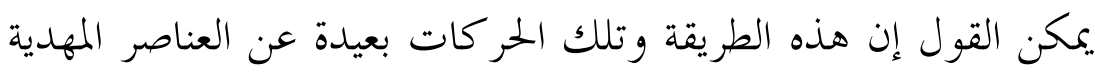
سواء كانت جاوية أو إسلامية.

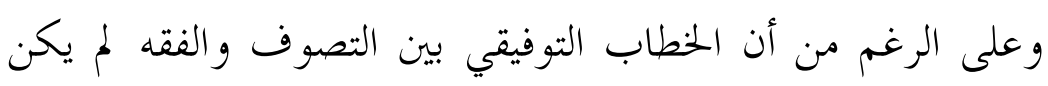

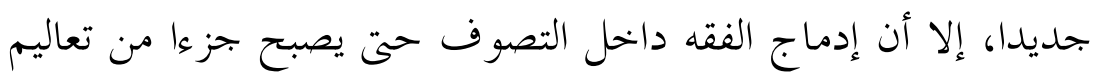

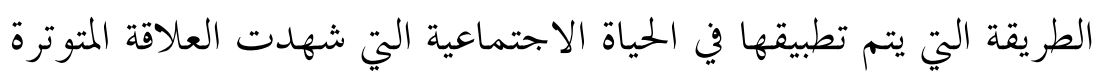

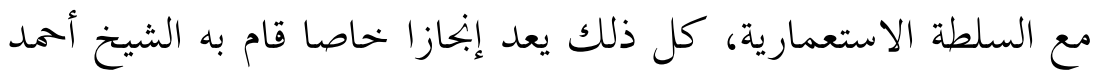

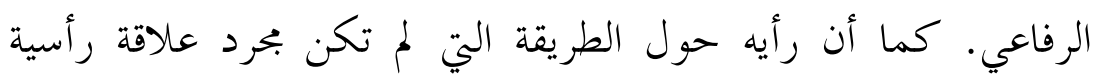

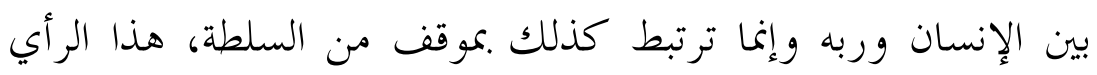

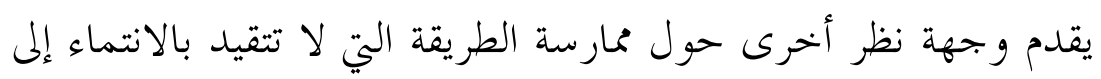

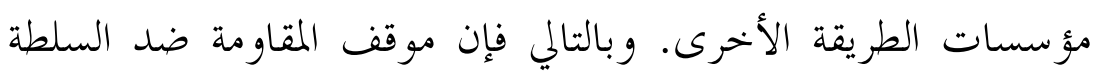
المستبدة يعد كذلك تطبيقا لتعاليم الطريقة نفسها طمعا في نيل رضا لئل الله. 
هذا المقال تطوير للمبحث الثالث من الفصل الساس للأطروحة التي قدمتها

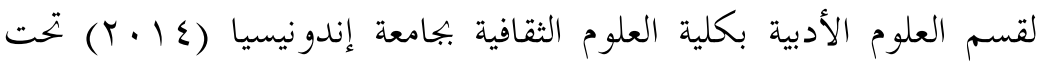

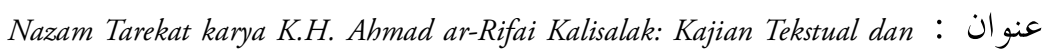

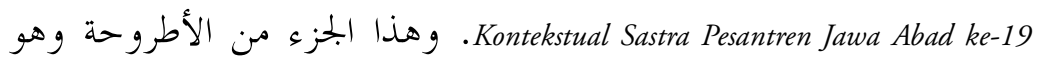
مراجعة المخطو ط وتحقيق النصوص مع الترجمة يتم نشره بشكل منفصل بعنو ان مان: Puisi Perlawanan dari Pesantren: Nazam Tarekat Karya K.H. Ahmad ar-Rifai Kalisalak $\cdot(Y \cdot 17)$

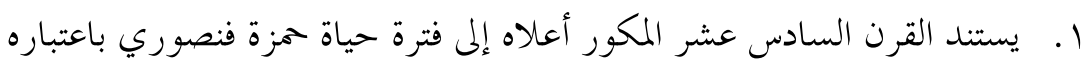
شخصية بارزة يعتقد أنه من أتباع الطريقة القادرية. أنظر : ,Bruinessen 1995) . 191; Drewes and Brakel 1986, 5-8)

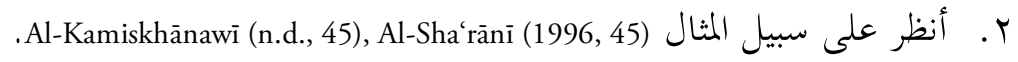

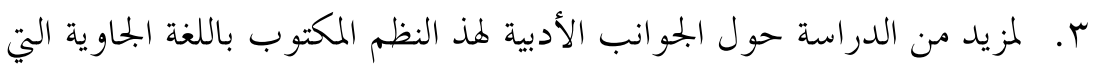

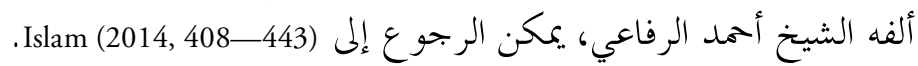

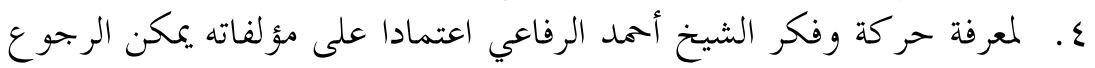

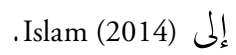

ه. . (2004, 36-37); Gusmian (2008, 85-87); Islam (2009, 33-34)

$$
\begin{aligned}
& \text { 7. Carey (2011,713-38) }
\end{aligned}
$$

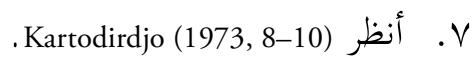

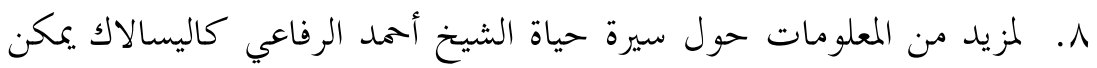
الرجوع إلى: جميل (Djamil 2001) و إسلام (Islam 2014) .

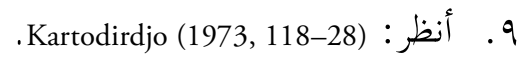

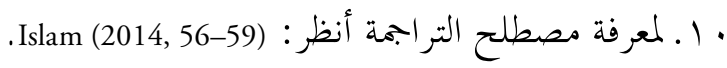

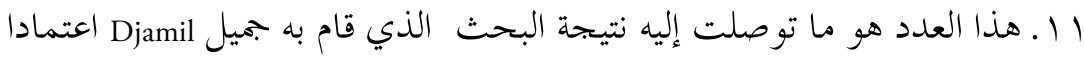

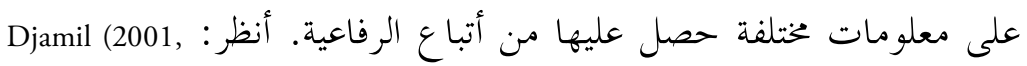
.xvii)

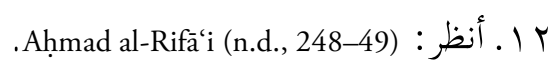

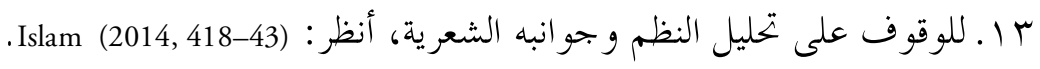


ع ا ـ لمعرفة شبكة مريديه و انتشار هم أنظر : Djamil (2001, 192-205).

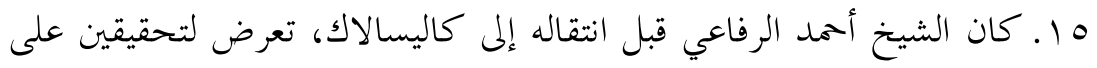

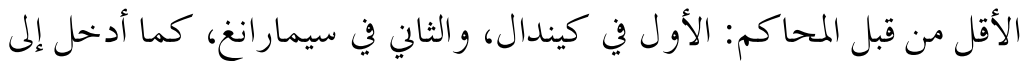
السجن مرتين (Amin 1996, 61-62)، و بعد أن استقر في كاليسالاك، تم التحقيق معه من قبل محكمة بيكالونغان اليت قررت في النهاية نفيه إلى خارج جاوة (Amin 1996, 80-85) . للوقوف على اعتبارات المحكمة التي قضت بنفيه يمكن فيك الرجوع إلى : Steenbrink $(1980,113)$

1 ا ـ إن اقتباسات نصوص نظم الطريقة الواردة في هذا المقال تعتمد على النصوص المو

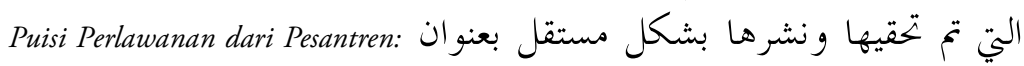
Nazam Tarekat, karya K.H. Ahmad ar-Rifai Kalisalak النصوص و اللغة الأصلية للهذا النظم، فقد تمت كتابة النصوص المقتبسة في هذا المقال بكروفها الأصلية ، وهي حروف جاوة البيجون. ولذلك الذكت تمت إحالة النصوص المقتبسة إلى صفحات ذلك الكتاب. V السلوك هو مسيرة إلى الله (Al-Hifnī 2003, 797). م ا ـ المقام هو المكانة الروحية الروحية التي وصل إليها الصوفي عن طريت المجاهدة الروحية و الرياضة و العبادة (Al-Hifnī 2003, 963) .

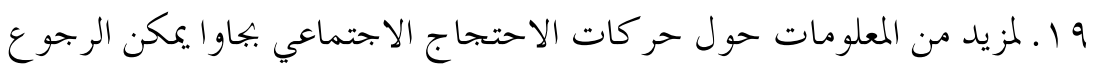
. Kartodirdjo (1973, : 21-106) :

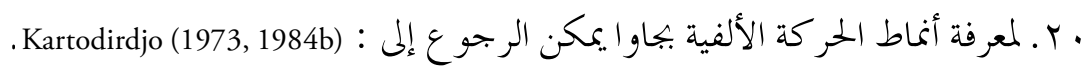

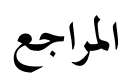

Amin, Ahmad Syadzirin. 1996. Gerakan Syaikh Ahmad Rifäi Dalam Menentang Kolonial Belanda. Jakarta: Jamaah Masjid Baiturrahman.

Azra, Azyumardi. 1999. Jaringan Ulama Timur Tengah dan Kepulauan Nusantara Abad XVII dan XVIII: Melacak Akar-Akar Pembaruan Pemikiran Islam di Indonesia. Jakarta: Mizan.

Bakrī, Sayyid. 1993a. Vol. 3 Hashīyah I'änat Al-Tälibìn 'alā Hall Alfäz Fatḥ AlMu'ìn. Beirut: Dār al-Fikr.

1993b. Vol. 4 Hashìyah I'ānat Al-Tâlibìn 'alā Hall Alfäz Fatḥ Al-Mu'ìn. Beirut: Dār al-Fikr. 
Al-Bayjūrī, Ibrahim. 1994a. Vol. 1 Hashīyah Al-Shaykh Ibrahim Al-Bayjūrī 'alā Sharh Al-Allàmah Ibn Qāsim Al-Ghāzì 'alā Matn Al-Shaykh Abì Shujā’. Beirut: Dār al-Fikr.

. 1994b. Vol. 2 Hashìah Al-Shaykh Ibrahim Al-Bayjūrì 'alā Sharh Al'Allāmah Ibn Qāsim Al-Ghāzì 'alà Matn Al-Shaykh Abì Shujā’. Beirut: Dār alFikr.

Benda, Harry J. 1980. Bulan Sabit Dan Matahari Terbit: Islam Di Indonesia Pada Masa Pendudukan Jepang. Jakarta: Pustaka Jaya.

Bruinessen, Martin van. 1995. Kitab Kuning, Pesantren, dan Tarekat: Tradisitradisi Islam di Indonesia. Bandung: Mizan.

Burhanudin, Jajat. 2012. Ulama \& Kekuasaan: Pergumulan Elite Muslim dalam Sejarah Indonesia. Bandung: Mizan.

Carey, Peter. 2011. Kuasa Ramalan: Pangeran Dipinegoro Dan Akhir Tatanan Lama Di Jawa, 1785-1855. Jakarta: Gramedia.

Darban, Ahmad Adabi. 2004. Rifa'iyyah, Gerakan Sosial Keagamaan Di Pedesaan Jawa Tengah Tahun 1850-1982. Yogyakarta: Terawang Press.

Djamil, Abdul. 2001. Perlawanan Kiai Desa: Pemikiran dan Gerakan Islam K.H. Ahmad Rifäi. Yogyakarta: LKiS.

Drewes, Gerardus Willebrordus Joannes, and L. F Brakel. 1986. The Poems of Hamzah Fansuri. Cinnaminson: Foris Publications.

Fathurahman, Oman. 2008. Tarekat Syattariyah di Minangkabau: Teks dan Konteks. Jakarta: Prenada Media Group.

— 2011. "Ithāāf Al-Dhakī by Ibrahim Al-Kūrānī: A Commentary of Wahdat Al-Wujūd for Jāwī Audiences." Archipel (81). http://cat.inist.fr/?aModele=affi cheN\&cpsidt=24119600 (June 13, 2016).

Al-Ghazālī, Abū Hāmid. 2004. Vol. 3 Ihyä̀' 'Ulūm Al-Dīn. ed. Sayyid Imrān. Kairo: Dār al-Hadīth.

Gusmian, Islah. 2008. "Pemikiran Islam Kiai Ahmad Rifa’i: Kajian Atas Naskah Tabsirah (KBG 486).” Lektur 6(1): 67-90.

al-Hasanī, Ahmad ibn Muhammad ibn 'Ajībah. 2009. Iqqäz Al-Himam Fì Sharh Al-Hikam. Kairo: Maktabah al-Shurūq al-Duwalīyah.

Al-Hifnī, 'Abd al-Mu'īn. 2003. Al-Mawsū'ah Al-Ṣüfìyah. Kairo: Maktabah Madbuli.

Hisyam, Muhamad. 2001. Caught Between Three Fires: The Javanese Pangulu Under The Dutch Colonial Administration 1882-1942. Jakarta: INIS.

Islam, M. Adib Misbachul. 2009. Kitab Takhyirah Karya K.H. Ahmad Rifäi Kalisalak: Teks Dan Konteks. 
2014. "Nazam Tarekat Karya KH. Ahmad Ar-Rifai Kalisalak: Kajian Tekstual Dan Kontekstual Sastra Pesantren Jawa Abad Ke-19.” Ph.D. Dissertation. Universitas Indonesia, Fakultas Ilmu Pengetahuan Budaya.

2016. Puisi Perlawanan Dari Pesantren: Nazam Tarekat Karya KH. Ahmad Ar-Rifai Kalisalak. Tangerang: Transpustaka.

Ismawati. 2004. "Jaringan Ulama Kendal Abad ke-19 dan 20.” Ph.D. Dissertation. Universitas Islam Negeri (UIN) Syarif Hidayatullah Jakarta.

Al-Kamiskhānawī, Ahmad. Jamī’ Al-Ușūl Fì Al-Awliyä̀. Singapore, Jeddah, Jakarta: al-Haramayn.

Kartodirdjo, Sartono. 1973. Protest Movement in Rural Java: A Study of Agrarian in the Nineteenth and Early Twentieth Centuries. Singapore: Oxford University Press.

-1984a. Pemberontakan Petani Banten 1888. Jakarta: Pustaka Jaya.

1984b. Ratu Adil. Jakarta: Penerbit Sinar Harapan.

Kartodirdjo, Sartono, A Sudewa, and Suhardjo Hatmosuprobo. 1987. Perkembangan Peradaban Priyayi. Yogakarta: Gadjah Mada University Press.

Khoiri, Alwan. 1996. "Corak TasawufYang Diajarkan K.H. Ahmad Rifa'i.” Ph.D. Dissertation. IAIN Syarif Hidayatullah Jakarta.

Al-Kurdī, Muhammad Amīn. 1994. Tanwīr Al-Qulūb Fì Mu'āmalat 'Allām AlGhuyūb. Beirut: Dār al-Fikr.

Lombard, Denys. 2005. Nusa Jawa: Kajian Sejarah Terpadu Bagian I: Warisan Kerajan-Kerajaan Konsentris. Jakarta: Gramedia Pustaka Utama.

Rahman, Fazlur. 2000. Islam. Bandung: Pustaka.

Ricklefs, M.C. 2007. Polarising Javanese Society: Islamic and Other Visions, C. 1830-1930. NUS Press.

al-Rifāci, Aḥmad. "Abyan Al-Hawaij.” Pekalongan. Manuskrip koleksi KH. Zainal Abidin.

Sharaf, Muhammad Jalāl. 1984. Dirāsat Fi Al-Taṣawwuf Al-Islāmī: Shakhșīyah Wa Madhāhib. Beirut: Dār al-Nahḍah al-Arabīyah.

Al-Sha'rānī, 'Abd al-Wahhāb. 1996. Lawāqịh Al-Anwār Al-Qudsīyah Fì Ma'rifat Qawāìd Al-Ṣüfìyah. Beirut: Dār al-Fikr.

Steenbrink, Karel A. (Karel Andrian). 1980. Beberapa Aspek Islam Di Indonesia Abad Ke-19. Jakarta: Bulan Bintang.

Suminto, Aqib. 1986. Politik Islam di Hindia Belanda. Jakarta: LP3ES.

Sutherland, Heather. 1983. Terbentuknya Sebuah Elite Birokrasi. Trans. Sunarto. Jakarta: Sinar Harapan. 
Al-Taftazanī, Abū al-Wafā al-Ghunaymī. 1969. Ibn "Atạ"illāh Al-Sakandarī Wa Tasawwufuhu. Ed. 2. Kairo: Maktabat al-Anglo al-Mișriyah.

1979. Madkhal Ilā Al-Tașawwuf Al-Islāmī. Kairo: Dār al-Thaqāfah li alNashr wa al-Tawzi ī.

Wahid, Abdurrahman. 1999. Prisma Pemikiran Gus Dur. Yogyakarta: LKIS.

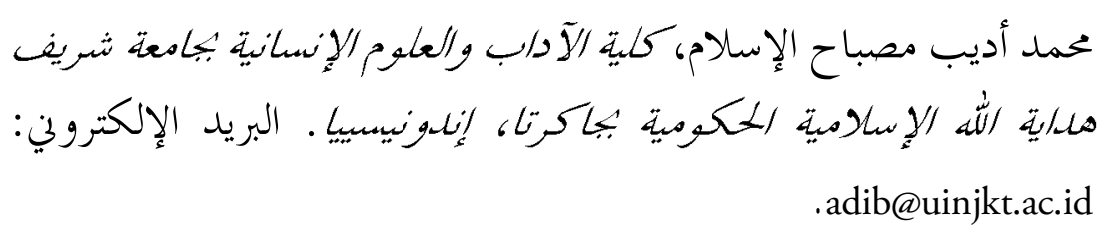


Indexes

\section{Studia Islamika: 2016}

\section{Volume 23, Number 1, 2016}

1. Ali Munhanif, Islam, Ethnicity and Secession: Forms of Cultural Mobilization in Aceh Rebellions.

2. Saifuddin Dhuhri, The Text of Conservatism: The Role of Abbas' Abl al-Sunnah wa al-Jamā'ah in Underpinning Acehnese Current Religious Violence.

3. Firman Noor, Leadership and Ideological Bond: PPP and Internal Fragmentation in Indonesia.

4. Eka Putra Wirman, Nazariyāt fì takāmul al-úūm: dirāsah naqdìyah wa ta'sisizyah fi thaqäfat al-Minangkabau.

5. M. Isa H.A. Salam, Al-Dawlah wa al-da'wah al-Islämìyah fì 'ahd al-nizām al-jadìd: dirāsah fī fikr Soeharto min khilāl al-khițābāt alri'àsīyah fì al-munāsabāt al-Islämīyah bi Indonesia.

6. Azyumardi Azra, Kontestasi Pemikiran Islam Indonesia Kontemporer.

7. Dadi Darmadi, Tears and Cheers in Jombang: Some Notes on the 33rd Nahdlatul Ulama Congress. 


\section{Volume 23, Number 2, 2016}

1. Asfa Widiyanto, The Reception of Seyyed Hossein Nasr's Ideas within the Indonesian Intellectual Landscape.

2. Andri Soemitra, Higher Objectives of Islamic Investment Products: Islamizing Indonesian Capital Market.

3. Hamka Siregar, Fiqh Issues in the Border Areas of West Kalimantan.

4. Rangga Eka Saputra, Hizb al-Adālah wa al-Rafāhīyah (PKS) wa siyāsāt al-huwīyah al-Islāmīyah: istiratijīyāt kawādir al-ḥizb li tàtīir qadāyā nukhabihim al-fasādìyah al-mālìyah.

5. Ismatu Ropi, Al-Islām wa al-madd wa al-jazr fì al-'alāqāt bayn al-dìn wa al-dawlah fì Indonesia.

6. Jajat Burhanudin, Pasang Surut Hubungan Aceh dan Turki Usmani: Perspektif Sejarah.

7. Endi Aulia Garadian, Between Identity and Interest: Revisiting Sharia Bylaw in Current Indonesia.

\section{Volume 23, Number 3, 2016}

1. Ahmad Rizky Mardhatillah Umar, A Genealogy of 'Moderate Islam': Governmentality and Discourses of Islam in Indonesia's Foreign Policy.

2. Motoki Yamaguchi, Islamic School and Arab Association: Abmad Sürkatī's Reformist Thought and Its Influence on the Educational Activities of al-Irshäd.

3. Muhammad Ansor, Post-Islamism and the Remaking of Islamic Public Sphere in Post-reform Indonesia.

4. M. Adib Misbachul Islam, Al-Ṭariqah wa al-harakah al-ihtijājīyah al-ijtimā'ìyah bi Jawa fì al-qarn al-tāsi' 'ashar: al-Shaykh Abmad alRifä̀i Kalisalak namüdhajan.

5. Muhamad Firdaus Ab Rahman \& Muhammad Amanullah, Ta'bid al-waqf wa tàqìtuhu fì wilāyāt mukhtārah fì Malaysia.

6. Zulkifli, Kesalehan 'Alawi dan Islam di Asia Tenggara.

7. Abdallah, Exclusivism and Radicalism in Schools: State Policy and Educational Politics Revisited. 


\section{Guidelines}

\section{Submission of Articles}

tudia Islamika, published three times a year since 1994, is a bilingual (English and Arabic), peer-reviewed journal, and specializes in Indonesian Islamic studies in particular and Southeast Asian Islamic studies in general. The aim is to provide readers with a better understanding of Indonesia and Southeast Asia's Muslim history and present developments through the publication of articles, research reports, and book reviews.

The journal invites scholars and experts working in all disciplines in the humanities and social sciences pertaining to Islam or Muslim societies. Articles should be original, research-based, unpublished and not under review for possible publication in other journals. All submitted papers are subject to review of the editors, editorial board, and blind reviewers. Submissions that violate our guidelines on formatting or length will be rejected without review.

Articles should be written in American English between approximately 10.000-15.000 words including text, all tables and figures, notes, references, and appendices intended for publication. All submission must include 150 words abstract and 5 keywords. Quotations, passages, and words in local or foreign languages should 
be translated into English. Studia Islamika accepts only electronic submissions. All manuscripts should be sent in Ms. Word to: http:// journal.uinjkt.ac.id/index.php/studia-islamika.

All notes must appear in the text as citations. A citation usually requires only the last name of the author(s), year of publication, and (sometimes) page numbers. For example: (Hefner 2009a, 45; Geertz 1966, 114). Explanatory footnotes may be included but should not be used for simple citations. All works cited must appear in the reference list at the end of the article. In matter of bibliographical style, Studia Islamika follows the American Political Science Association (APSA) manual style, such as below:

1. Hefner, Robert. 2009a. "Introduction: The Political Cultures of Islamic Education in Southeast Asia," in Making Modern Muslims: The Politics of Islamic Education in Southeast Asia, ed. Robert Hefner, Honolulu: University of Hawai'i Press.

2. Booth, Anne. 1988. "Living Standards and the Distribution of Income in Colonial Indonesia: A Review of the Evidence." Journal of Southeast Asian Studies 19(2): 310-34.

3. Feener, Michael R., and Mark E. Cammack, eds. 2007. Islamic Law in Contemporary Indonesia: Ideas and Institutions. Cambridge: Islamic Legal Studies Program.

4. Wahid, Din. 2014. Nurturing Salafi Manhaj: A Study of Salafi Pesantrens in Contemporary Indonesia. PhD dissertation. Utrecht University.

5. Utriza, Ayang. 2008. "Mencari Model Kerukunan Antaragama." Kompas. March 19: 59.

6. Ms. Undhang-Undhang Banten, L.Or.5598, Leiden University.

7. Interview with K.H. Sahal Mahfudz, Kajen, Pati, June $11^{\text {th }}$, 2007.

Arabic romanization should be written as follows:

Letters: ', $b, t, t h, j, h, k h, d, d h, r, z, s, s h, s, d, t, z, ', g h, f, q, l$, $m, n, h, w, y$. Short vowels: $a, i, u$. long vowels: $\overline{\mathrm{a}}, \overline{\mathrm{i}}, \overline{\mathrm{u}}$. Diphthongs: $a w$, ay. Tà marbūtāa: t. Article: al-. For detail information on Arabic Romanization, please refer the transliteration system of the Library of Congress (LC) Guidelines. 
ستوديا إسلاميكا (ISSN 0215-0492; E-ISSN: 2355-6145) بحلة علمية دولية محكمة تصدر عن مركز دراسات الإسلام والمجتمع (PPIM) بجامعة شريف هداية الله الإسلامية الحكومية بجاكرتا، تعنى بدراسة الإسلام في إندونيسيا خاصة وفي جنوب شرقي آسيا عامة. وتستهدف المجلة نشر البحوث العلمية الأصيلة والقضايا المعاصرة حول الموضوع، كما ترحب بإسهامات الباحثين أصحاب التخصصات ذات الصلة. وتخضع جميع الأبحاث المقدمة للمجلة للتحكيم من قبل للجنة غختصة. تم اعتماد ستوديا إسلاميكا من قبل وزارة التعليم و الثقافة بجمهورية إندونيسيا باعتبارها دورية علمية (قرار المدير العام للتعليم العالي رقم: 56/DIKTI/Kep/2012).

ستوديا إسلاميكا عضو في CrossRef (الإحالات الثابتة في الأدبيات الأكاديمية) منذ ع ا ـ ب، و بالتالي فإن جميع المقالات التي نشرقا مرقمة حسب معرّف الوثيقة الرقمية (DOI) . ستوديا إسلاميكا بحلة مفهرسة في سكوبس (Scopus) منذ .ب مايو 0 • •r. ولذلك، فإن جميع المقالات المنشورة منذ 10 . r ستظهر هناك.

\author{
حقوق الطبعة محفوظة \\ عنو ان المر اسلة:
}

Editorial Office: STUDIA ISLAMIKA, Gedung Pusat Pengkajian Islam dan Masyarakat (PPIM) UIN Jakarta, Jl. Kertamukti No. 5, Pisangan Barat, Cirendeu, Ciputat 15419, Jakarta, Indonesia. Phone: (62-21) 7423543, 7499272, Fax: (62-21) 7408633; E-mail: studia.islamika@uinjkt.ac.id Website: http://journal.uinjkt.ac.id/index.php/studia-islamika

$$
\begin{aligned}
& \text { قيمة الاشتر اك السنوي خار ج إندونيسيا: }
\end{aligned}
$$

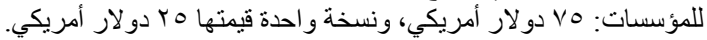

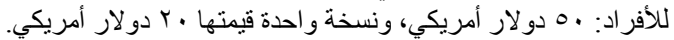

$$
\begin{aligned}
& \text { والقيمة لا تشمل نفقة الإرسال بالبريد الجويكية وندي. }
\end{aligned}
$$

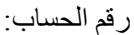

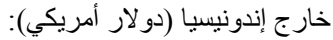

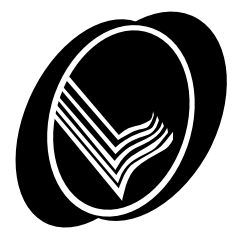




\section{ستوديا إسلاميكا}

مجلة إندونيسيا للار اسات الإسلامية

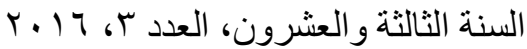

$$
\begin{aligned}
& \text { رئيس التحرير: } \\
& \text { مدير التحرير: }
\end{aligned}
$$$$
\text { هيئة التحريز : - مي }
$$$$
\text { سميف المزاني }
$$

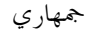

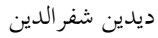

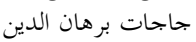

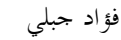
علي منحنف

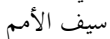

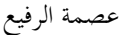

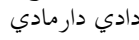

جاجانج جهراني

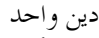
آيانج أوتريزا يقين

تممد قريش شهاب (جامعة شريف هداية الله الإسلامية الحكومية بجاكرتا)

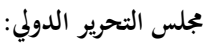

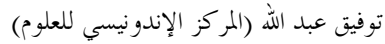
نور أ. فاضل لوبيس (الجامعة الإسلامية الحكومية سومطرة الشمالية) مثر ش. ريكليف (جامعة أستراليا الحكومية كانيراية)

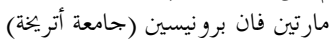

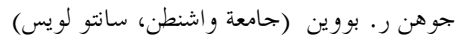

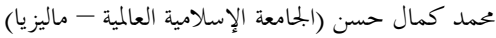
فر كنيا م. هو كير (جامعة أستراليا الحكومية كانبيرا) إيدوين ف. ويرنبا (جامعة كولونيا، ألمانيا)

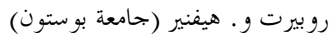
ريكي مادينير (المركز القومي للبحث العلمي بفرنسا) ريكائ فيائل فينير (جامعة أكسفورد) ميكائيل ف. لفان (جامعة فرينشتون)

مساعد هيئة التحرير: تيستريونو محمد نداء فضلان

مراجعة اللغة الإنجليزية: شير بلي باكير الإبلنية

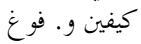
مراجعة اللغة العربية: تو بورضمد أدي أسناوي تصميم الغلاف: س. - (برنكا 



\section{لالتوايا السالمسيا}


111

السنة الثالثة و العشرون، العدد ب، 7 ا •

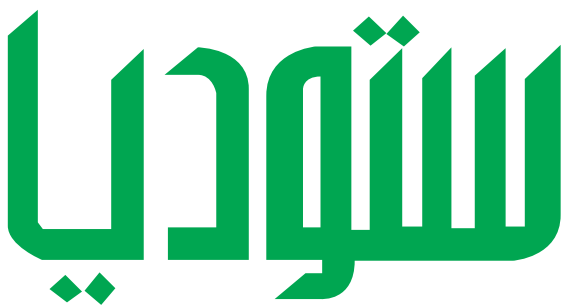

بجلة إندونيسية للدراسات الإسلامية

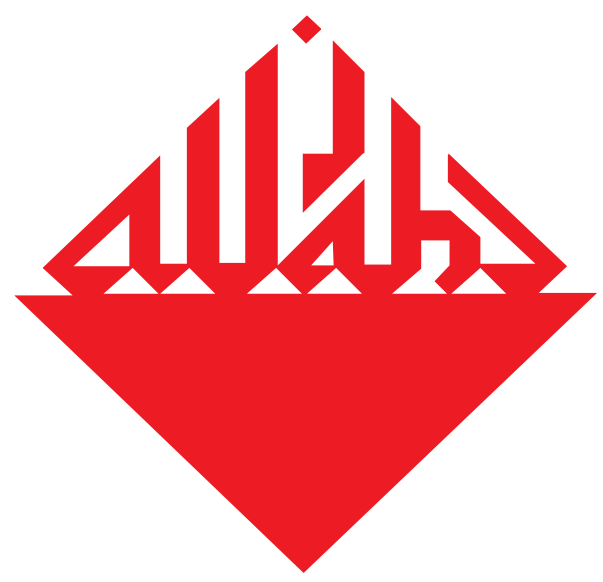

الطريتة والمركة الاتزباجية

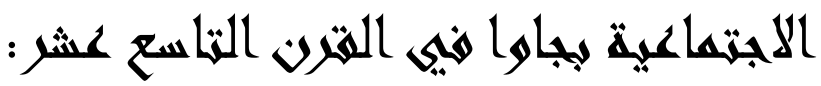

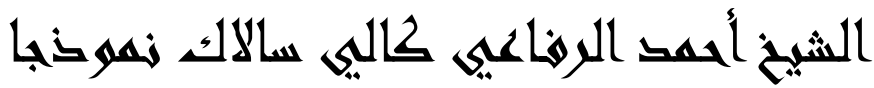

محمد أديب مصباح الإسلام

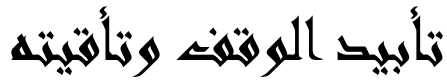

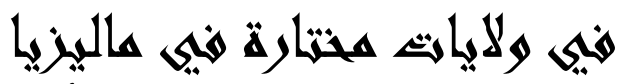

محمد فردوس عبد الرحمن ومحمد أمان الله الله 